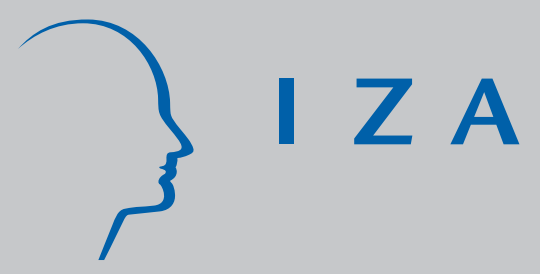

IZADP No. 2225

\title{
Consensual and Conflictual Democratization
}

Matteo Cervellati

Piergiuseppe Fortunato

Uwe Sunde

July 2006 


\title{
Consensual and Conflictual Democratization
}

\author{
Matteo Cervellati \\ University of Bologna, IAE Barcelona \\ and IZA Bonn \\ Piergiuseppe Fortunato \\ University of Bologna \\ Uwe Sunde \\ IZA Bonn and University of Bonn
}

Discussion Paper No. 2225
July 2006

IZA

P.O. Box 7240

53072 Bonn

Germany

Phone: +49-228-3894-0

Fax: +49-228-3894-180

Email: iza@iza.org

\begin{abstract}
Any opinions expressed here are those of the author(s) and not those of the institute. Research disseminated by IZA may include views on policy, but the institute itself takes no institutional policy positions.

The Institute for the Study of Labor (IZA) in Bonn is a local and virtual international research center and a place of communication between science, politics and business. IZA is an independent nonprofit company supported by Deutsche Post World Net. The center is associated with the University of Bonn and offers a stimulating research environment through its research networks, research support, and visitors and doctoral programs. IZA engages in (i) original and internationally competitive research in all fields of labor economics, (ii) development of policy concepts, and (iii) dissemination of research results and concepts to the interested public.
\end{abstract}

IZA Discussion Papers often represent preliminary work and are circulated to encourage discussion. Citation of such a paper should account for its provisional character. A revised version may be available directly from the author. 


\section{ABSTRACT}

\section{Consensual and Conflictual Democratization*}

We study the process of endogenous democratization from inefficient oligarchic systems in an economy where heterogeneous individuals can get involved in predation activities. The features of democracies are shown to be crucially related to the conditions under which democratization initially takes place. The political regime and the extent of redistribution implemented under it depend on the allocation of de facto political power across the different social groups. The cost of public enforcement of property rights depends on the extent of predation activities in the economy. The theory highlights the importance of inequality in natural resources and availability of human capital for endogenous democratic transitions. Multiple politico-economic equilibria can be sustained conditional on expectations about property rights enforcement. This generates history dependence. Democratic transitions supported by a large consensus serve as coordination device and lead to better protection of property and more stable political systems than democratic transitions imposed in conflictual environments. We test the novel predictions using available cross-country data. The link between the type of democratic transition and the outcomes under democracy is also investigated using novel data on constitutional principles. The findings support the theoretical predictions.

JEL Classification: H10, O20, N10

Keywords: democratization, oligarchy, conflict, consensual democracy, inequality, commitment, constitutional principles

Corresponding author:

Uwe Sunde

IZA

Schaumburg-Lippe Str. 9

D-53113 Bonn

Germany

E-mail: sunde@iza.org

\footnotetext{
* The authors wish to thank Graziella Bertocchi, Matthias Doepke, Eliana La Ferrara, Philipp Harms, Humberto Llavador, Karl Ove Moene, Debraj Ray, Sevi Rodriguez Mora, Ken Sokoloff, and seminar participants at Aachen, Bologna, Carlos III Madrid, Paris I, and at the ESEM/EEA Meetings 2004 in Madrid for helpful comments and suggestions on earlier versions of the paper. Financial support from IZA is gratefully acknowledged.
} 


\section{Introduction}

This paper analyzes the endogenous emergence of political systems, such as oligarchies and democracies, and growth enhancing economic policies like public enforcement of property rights. The model studies the feedbacks between the political institutions and economic outcomes, and the consequences for the process of economic development. We propose a theory in which the efficiency features of the emerging democracies are crucially related to the conditions under which the process of democratization takes place: under a broad consensus among the groups of society, or under conflict between different groups.

Formally, the theoretical analysis is developed within a dynamic general equilibrium model in which the relative importance of different factors of production, most notably human capital and natural resources, changes during the process of development. These productive factors are unequally distributed among different social groups. All individuals can decide to divert part of their economic resources to predation activities which serve both offensive and defensive purposes. Property rights can be enforced by the state but only at a cost that depends on the structural features of the economy. In particular the cost of enforcing claims to private property increases with the extent of predation activities in the population. Apart from providing protection of property rights, the state can use the tax-financed public budget to redistribute incomes. Political decisions therefore pertain to the size of the budget, as well as the allocation of fiscal revenues to redistribution and property rights protection.

We consider two extreme cases of political systems: oligarchy, in which de jure political power is restricted to a rich minority elite, and democracy, in which the political franchise is universal. Under any political regime the decisions concerning public policies are made by all individuals endowed with de jure political power. This implies that the elite alone can choose public policies in an oligarchy, while the elite's control over government choices is limited in a democracy. The fact that politically enfranchised individuals have the possibility to determine size and beneficiary of redistribution generates the main conflict of interest. Democracies are not assumed to be intrinsically more efficient or better suited for property rights protection than oligarchies. Under both regimes, the state has no possibility to commit to public policies, property rights enforcement or redistribution.

The choice of the political system is endogenous. We consider a framework in which the decision about the political regime is made rationally by the social group with the larger de facto political power. Political power is modelled as a "guns" model in which the ability to influence the regime implementation (and therefore the allocation of de jure political power) is 
related to the relative conflict potential of the different groups in terms of availability of "guns" and "gunners". The distribution of de facto political power is therefore crucially related to the control of economic resources and changes over time.

At each moment in time a politico-economic equilibrium is characterized by the mutually consistent individual predation choices, public policies, and the endogenously emerging political regime. The features of the politico-economic equilibria depend on the level of economic development and on the degree of economic inequality.

The model delivers several novel results concerning the determinants of a democratic transition, the economic efficiency of democratization and the subsequent development path. Initially the economy is characterized by an inefficient oligarchic system with poor protection of property rights and widespread predating activities. This inefficient system persists as long as it represents the best option for the elite and, at the same time, the ruling class is sufficiently strong to retain power. ${ }^{1}$ Democratization can be endogenously enforced, however, by the disenfranchised population under the shadow of conflict and against the will and the interests of the ruling class. This transition scenario is in line with arguments proposed by Acemoglu and Robinson (2000, 2001 and 2005) and Acemoglu, Johnson and Robinson (2005). They consider a situation, in which an elite faces revolutionary threats. In the absence of a possibility to commit to fiscal policies, the elite is forced to extend the franchise. Conley and Temimi (2001) and Bertocchi and Spagat (2001) provide similar theories in which a larger conflict potential of the disenfranchised population increases the likelihood for them to be allocated voting rights. Our theory also delivers the possibility of an alternative transition scenario in which the process of democratization may represent a Pareto-improvement. By benefitting all social groups through better property rights protection, a democratic transition may thus be supported by a large consensus in society, including the entrenched ruling elite. Democratic transitions that are driven by efficiency-enhancing features have been studied previously. Bourguignon and Verdier (2000) argue that democracies can arise because they provide a better environment for public education. According to Lizzeri and Persico (2004) democratic extensions in Britain may be initiated because they facilitate the political implementation of public policies that benefit the community at large. Llavador and Oxoby (2005) study the possibility that an elite which is divided over different economic interests extends the franchise to get larger support for the implementation of

\footnotetext{
${ }^{1}$ The study of the emergence of persistence of inefficient institutions is attracting increasing research effort. Similarly to Acemoglu (2006) we find that necessary conditions for an inefficient system to persist are the existence of distortions that prevents the elite to extract rents from the implementation of more efficient equilibria, and the fact that the elite are sufficiently entrenched.
} 
better policies. In Gradstein (2006) democratization permits the public protection of property rights since the newly enfranchised, the poor, do not suffer from commitment problems that prevent its implementation.

The proposed benchmark allows to study the different transition scenarios within a unified framework and it provides a taxonomy of the economic conditions under which they arise. Economic inequality, and ultimately the initial concentration of the control over productive factors like natural resources, is the primary determinant of the type of democratic transition. Most importantly, the theory predicts that the efficiency of the economic policies which emerge in democracies, and of the subsequent development path, crucially depends on the conditions under which democratization initially takes place. While democracies that arise under a consensus create more favorable environments for economic development, democracies that arise under the shadow of conflict do not necessarily perform better than non-democracies. In terms of fiscal policies, consensual democracies implement larger fiscal redistribution and have larger governments.

A second set of results relates to the existence of multiple politico-economic equilibria that arises from expectations about policies. In the absence of the possibility to commit to public policies, individual predation choices are made conditional on the expectations about property rights enforcement. The expectation of poor protection of property induces individuals to protect themselves by getting involved in predation activities. The enforcement of property rights is not possible ex post if these predation activities are sufficiently pervasive in the population. This implies that the possibility to implement property rights crucially depends on the ex ante individual expectations about the possibilities of their enforcement ex post. Expectations about poor property rights protection are therefore self-fulfilling in equilibrium. It turns out that this is the case regardless of the prevailing economic conditions and the political system in place. Consequently, the population faces a coordination dilemma. The different types of democratic transitions, however, not only influence the efficiency that can be achieved by a democratic system, but also affect the possibility to solve this coordination problem. A consensual democratization, voluntarily initiated and supported by an entrenched elite, can serve as a signal to coordinate the society's expectations about the emergence of 'good' economic policies. When democracy is imposed in a conflictual environment, however, democratization does not represent an effective coordination device. This result implies history dependence. Countries that experienced conflictual transitions to democracy may fail to protect property rights even if this eventually becomes feasible. 
The paper relates to the ongoing debate about the determinants of democratization. Several authors have found evidence for a positive effect of income per capita on the emergence and prevalence of democratic structures. Whether this constitutes a causal effect is still an issue of debate, however. ${ }^{2}$ Recent evidence suggests that the level of income per capita potentially only plays an instrumental role for political change and democratization, while inequality constitutes a more relevant determinant. The predictions of our model that inequality and availability of human capital are crucial determinants of democratic transitions and the quality of the democratic institutions conform to these findings. They also conform to the original argument of Lipset $(1959,1960)$ that high levels of economic well-being, but in particular also low levels of inequality and a relatively large importance of human capital are crucial for democracy.

The paper also relates to the empirical debate on the consequences of democracy for economic development and the adoption of growth enhancing institutions. Some studies have found evidence of a direct positive effect of democracy or democratization on growth, others have rejected a direct causal effect of democracy on growth. ${ }^{3}$ Our theory predicts that, depending on the conditions under which it takes place, democratization can causally facilitate institutional improvements although it is not sufficient to guarantee economic development. This is in line with the evidence supporting the view that democracies are not necessarily superior per se but potentially play an instrumental role for the implementation of better institutions and policies.

Beyond discussing the theoretical implications in light of the existing empirical literature, we test the novel predictions using cross country data in the second part of this paper. According to the theory the implementation of growth-enhancing structures in democracies is crucially related to the democratic transition, and particularly to the conditions in terms of inequality during the transition stage. Naive regressions using cross-sectional data correspond well to the theoretical predictions. To address potential problems of endogeneity, we also apply an instrumentation strategy based on the argument by Engerman and Sokoloff $(1997,2001)$ along the lines of Easterly (2001) and use measures of initial inequality and exogenous geographical characteristics to instrument inequality. The empirical results broadly support the theoretical predictions. In particular, we find that a lower concentration in the ownership of natural resources favors consensual democracies in which property rights are better protected. We also find support for the prediction that the existence of democratic institutions is not a sufficient condition for the quality of economic policies like property rights protection, while inequality is their crucial

\footnotetext{
${ }^{2}$ See, e.g. Acemoglu et al. (2005). We discuss the empirical literature in more detail in section 5.

${ }^{3}$ The contributions of, e.g., Rodrik and Wacziarg (2005) and Glaeser et al. (2004), respectively, recently contributed to this debate. We provide brief overview over the literature in Section 5 .
} 
determinant. Moreover inequality at the time of the democratic transition as indicator for the type of the transition largely determines the extent and limits of taxation and redistribution, the extent of predation reflected by expropriation risk, rent-seeking activities and political stability under the democratic systems we observe today.

To investigate the political mechanism proposed in the model, we also collect data on the principles of property rights protection stated in the democratic constitutions. The idea behind this empirical strategy is that the conditions under which democratic transitions occur are related to the allocation of political power among the different social groups. This allocation of power and the different interests of the social groups is reflected in the constituent assembly, and consequently materializes in the principles and aims encoded in the constitutional articles. The data therefore reflect the constitutional foundations underlying the realized outcomes of property rights protection. The results provide support for the prediction that the degree of inequality at the moment of the transition determines the constitutional principles of emerging democracies. These constitutional principles regarding property rights and expropriation in turn affect the observed outcomes of actual property rights enforcement and protection from expropriation.

The remainder of the paper proceeds as follows. Section 2 introduces the economic framework and the politico-economic environment, describing the political regimes, the political decisions about policies, and the regime implementation. In section 3 we derive the different types of equilibria and we study the role of expectations for their emergence. Section 4 presents results on the development dynamics as well as a taxonomy of the politico-economic equilibria. In section 5 , we discuss the results in view of the empirical and historical literature while in section 6 we perform an empirical investigation of the novel predictions. Section 7 concludes.

\section{The Model}

Set up. Consider an economy populated by overlapping generations of individuals. There is no population growth, and each generation $t$ consists of a continuum of individuals $i$ of measure $L_{t}=L \forall t$. In the following, $i$ interchangeably denotes an individual and the family or dynasty to which the individual belongs. Individuals live for two periods. During the first period, they receive education and form $h_{t}$ units of human capital. Additionally, each individual has one unit of (homogeneous) labor at its disposal. In the second period production takes place and disposable income is realized and consumed. Each generation $t$ has a stock of natural resources (or land) $N_{t}=N$, a stock of human capital $H_{t}$ and labor $L_{t}=L$ at its disposal. While land 
does not depreciate, human capital fully depreciates when the generation dies. We denote per capita variables by lower case letters e.g. $y_{t}=Y_{t} / L, h_{t}$, and $n=N / L$. Individuals belong to one of two groups, which differ with respect to their possession of natural resources. All available natural resources $N$ are equally distributed among one group with size $0<\gamma<1 / 2$, the elite, which is denoted by $E$ so that $n_{t}^{E}=n / \gamma$. The remaining population is referred to as the people and denoted by $P$, with $n_{t}^{P} \equiv 0 .{ }^{4}$ Vectors are denoted with bold letters so that $\mathbf{y}_{t} \equiv\left\{y_{t}^{E}, y_{t}^{P}\right\}$.

Factor Income. A unique commodity is produced with an aggregate production function,

$$
Y_{t}=Y\left(A_{t} H_{t}, L, N\right)
$$

that exhibits positive but decreasing marginal productivity of all inputs, Inada conditions and constant returns to scale. Furthermore, productivity, $A_{t}$, is human capital augmenting and $H$ and $N$ are substitutes. ${ }^{5}$ Factor prices are determined competitively on the market and equal marginal productivity: $w_{t}=\partial Y_{t} / \partial L, r_{t}=\partial Y_{t} / \partial H_{t}$ and $\rho_{t}=\partial Y_{t} / \partial N$. Individual factor income, obtained supplying endowments to the market is given by,

$$
y_{t}^{i}=w_{t}+r_{t} h_{t}^{i}+\rho_{t} n^{i} \quad, i=E, P
$$

Technological progress depends on the available stock of human capital,

$$
\frac{A_{t}-A_{t-1}}{A_{t-1}}=a\left(H_{t-1}\right)
$$

with $a^{\prime}(\cdot)>0$. This formulation follows the endogenous growth literature along the lines of Nelson and Phelps (1966), Lucas (1988) and Romer (1990), in which human capital acquired by one generation exerts an externality on productivity of the next generation. Technical progress is biased and augments the productivity of human capital. ${ }^{6}$ The features of the production function and of technological progress imply that the available stock of human capital in a given generation indirectly makes human capital a more important source of income, relative to natural resources, for the future generations.

\footnotetext{
${ }^{4}$ The assumption that the people own no land is without loss of generality. All that is required for the analysis is inequality in terms of resource endowments.

${ }^{5}$ An example of a neoclassical production function satisfying these assumptions is $Y_{t}=\left(A_{t} H_{t}+N\right)^{\alpha}\left(L_{t}\right)^{1-\alpha}$, with $0<\alpha<1$. Equivalently one could adopt a technology with one commodity being produced in two sectors, with labor being optimally allocated across sectors like, e.g. $Y_{t}=Y_{t}^{T}+Y_{t}^{M}=N^{\alpha} L_{t}^{T 1-\alpha}+H_{t}^{\alpha}\left(A_{t} L_{t}^{M}\right)^{1-\alpha}$, where sector $T$ is natural resource intensive while sector $M$ is human capital intensive.

${ }^{6}$ Any formulation implying a positive relationship between human capital and technological progress is equivalent for the results.
} 
Predation. The entitlement to factor incomes is not exogenously ensured unless property rights are protected. Individuals decide whether to invest part of their income in illegal "predating" activities or abstain from this investment. Consider the following predation game played by each generation $t$ : after factor income $y_{t}^{i}$ is produced, individuals face the choice of either not predate or predate,

$$
p_{t}=\{0,1\}
$$

where $p_{t}=1$ means predation.

The costs for investing in predation imply foregoing a fraction $\varphi$ of factor income. This investment insures full protection from other individuals as well as from the state, e.g. from fiscal imposition. ${ }^{7}$ Individuals that do not predate pay taxes on their factor income $y_{t}^{i}$ and receive a post tax income denoted by $\widetilde{y}_{t}^{i}$.

After the predation decision individuals are matched in pairs: any agent $i \in\{E, P\}$ randomly meets an agent $j \in\{E, P\}$. If two predating individuals meet, no transfer of income takes place and they are both left with a disposable income given by $x_{t}^{i}=(1-\varphi) y_{t}^{i}$. Conversely, if two agents that have not invested in predation are matched, they both receive post-tax disposable income equal to $x_{t}^{i}=\widetilde{y}_{t}^{i}$. The payoff of a match between a predator and a non predator depends on the degree of property rights protection, however. If the state does not enforce property rights then predating agents can successfully expropriate non predating ones. In this case, the predator keeps all his income (net of predation costs) and he also appropriates the income of the other agent. ${ }^{8}$ This scenario is depicted in Figure 1.

Conversely, if the state does enforce property rights, no transfer of income takes place between a predator and an individual that does not predate. This scenario is depicted in Figure 2.

Public Policies. The state has two functions: protection of property rights and redistribution of income. Enforcement of property rights in each generation $t$ is modelled as a binary choice denoted by $c_{t}$ (e.g. for courts), given by

$$
c_{t}=\{0,1\}
$$

\footnotetext{
${ }^{7}$ This defensive role of predation investments can be interpreted as giving the individual the possibility to privately protect his property rights both against fellows citizens and the state, therefore providing a private substitute for property rights institutions in the sense of Acemoglu and Johnson (2005).

${ }^{8}$ This modelling strategy implies, for simplicity, that predating investment serves both an offensive and a defensive role. Models in which these two activities are separately investigated have been presented by Grossman and $\operatorname{Kim}$ (1995, 1996) and Grossman (2001).
} 
Figure 1: Predation Game without Enforcement of Property Rights

\begin{tabular}{c|c|c|}
$i^{j}$ & $\begin{array}{c}\text { Predate } \\
\left(p_{t}=1\right)\end{array}$ & $\begin{array}{c}\text { No Predate } \\
\left(p_{t}=0\right)\end{array}$ \\
\hline Predate $\left(p_{t}=1\right)$ & $y_{t}^{i}(1-\varphi)$ & $y_{t}^{i}(1-\varphi)+y_{t}^{j}$ \\
$y_{t}^{j}(1-\varphi)$ & 0 \\
\hline No Predate $\left(p_{t}=0\right)$ & 0 & $\tilde{y}_{t}^{i}$ \\
\hline
\end{tabular}

Figure 2: Predation Game with Enforcement of Property Rights

\begin{tabular}{c|c|c|}
$i^{j}$ & $\begin{array}{c}\text { Predate } \\
\left(p_{t}=1\right)\end{array}$ & $\begin{array}{c}\text { No Predate } \\
\left(p_{t}=1\right)\end{array}$ \\
\hline Predate $\left(p_{t}=1\right)$ & $y_{t}^{i}(1-\varphi)$ & $y_{t}^{i}(1-\varphi)$ \\
& $y_{t}^{j}(1-\varphi)$ & $\tilde{y}_{t}^{j}$ \\
\hline No Predate $\left(p_{t}=0\right)$ & $\tilde{y}_{t}^{i}$ & $\tilde{y}_{t}^{i}$ \\
& $y_{t}^{j}(1-\varphi)$ & $\tilde{y}_{t}^{j}$ \\
\hline
\end{tabular}

where $c_{t}=0$ means absence of enforcement. The cost of property right protection is given by $G_{t}$. We assume this cost to be non-decreasing in the share of population involved in predating activities denoted by $\pi_{t}$. This implies that the ex post per-capita cost of public property rights enforcement depends on the number of predators,

$$
G_{t}=\left\{\begin{array}{l}
G\left(\pi_{t}\right) \text { if } c_{t}=1 \\
0 \text { if } c_{t}=0
\end{array}\right.
$$

with $G(0)=0$ and $G^{\prime}\left(\pi_{t}\right) \geq 0 .{ }^{9}$ For simplicity, we assume that property rights enforcement is prohibitively costly if too many individuals predate. In particular, enforcement is feasible and involves no cost, unless a majority of population predates: $G(\pi>1 / 2)=\infty$ and $G(\pi \leq 1 / 2)=$ $0 .^{10}$

\footnotetext{
${ }^{9}$ This is in line with the argument proposed by Andvig and Moene (1990).

${ }^{10}$ These specific assumptions about the functional form of $G_{t}$ are merely made to simplify illustration and not
} 
Apart from enforcement of property rights, revenues from taxation can also be used for fiscal redistribution. Denoting by $R_{t}$ the total resources used for income redistribution and by $T_{t}$ the total fiscal revenue, the public budget constraint is therefore given by,

$$
T_{t} \geq R_{t}+G_{t}
$$

Fiscal redistribution, which is endogenously chosen by the population as studied below, can be either progressive or regressive. The taxation schedule implemented by a generation $t$, denoted by $f_{t}$, associates to any taxable pre-tax income a level of net post-tax income,

$$
\widetilde{y}_{t}^{i}=f_{t}\left(y_{t}^{i}\right)
$$

This schedule is constrained by the usual condition that excludes the possibility to re-rank individuals in the income distribution through redistribution:

$$
\frac{\partial f_{t}\left(y_{t}^{i}\right)}{\partial y_{t}^{i}} \geq 0
$$

This implies that progressive redistribution can achieve at most full equalization of incomes.

Political Regimes. The political system can be characterized by different political regimes: democracy and oligarchy, denoted by

$$
r_{t}=\{\mathrm{o}, \mathrm{d}\}
$$

These regimes differ with respect to the extension of the political franchise. Under oligarchy only the elite is enfranchised while under democracy the franchise is universal. The decisions about property rights protection and fiscal redistribution, $\{c, f\}$, are taken by the majority of the enfranchised population. This implies that public policies are chosen by the elite in oligarchies and by the people in democracies.

The political regime is chosen by the group with the larger de facto political power. This is formalized using a simple "guns model". The group that is able to mobilize more guns and gunners chooses the political regime. ${ }^{11}$ Political power is increasing in both the income and the essential for the qualitative results.

${ }^{11}$ We only adopt the reduced form notion of a "guns" model for simplicity and to focus attention on the main argument. The guns representation can be seen as the reduced form of a micro-founded conflict game, like a war of attrition game, in which the group with larger conflict potential has an advantage in the choice of allocation of de jure political power, i.e. political franchise. This can also be interpreted as a shadow of conflict in which the stronger group in terms of threat potential is allowed to choose. 
size of the respective group, $g\left(\gamma^{i} y_{t}^{i}\right)$ with $g^{\prime}(\cdot)>0$. The elite has the power to choose the regime if

$$
g\left(y_{t}^{E} \gamma\right)>g\left(y_{t}^{P}(1-\gamma)\right)
$$

while if

$$
g\left(y_{t}^{E} \gamma\right) \leq g\left(y_{t}^{P}(1-\gamma)\right)
$$

this decision is taken by the people. ${ }^{12}$

Timing. For a given generation $t$, the sequence of events and decisions is as follows: First period of life. Acquisition of human capital;

Second period of life. Production of factor income; politico-economic decisions made as follows:

1. The most powerful group, according to conditions (11) and (12), chooses the political regime $r_{t}$;

2. Each individual $i$ decides predation $p_{t}^{i}$;

3. Public Policies $\left\{c_{t}, f_{t}\right\}$ are chosen by the majority of the enfranchised population;

4. Individuals are randomly matched in pairs;

5. Public policies are implemented and disposable incomes $x_{t}^{i}$ are realized, according to the games illustrated in Figures 1 or 2.

Notice that this timing implies that under no political regime there is a possibility to commit to redistribution and property rights protection. Studying the emergence of equilibria in the absence of commitment allows to restrict attention to the endogenous emergence of politicoeconomic outcomes that are self-sustaining, i.e. compatible with the different incentives of the different social groups and with the distribution of de facto political power, and feasible in the sense that property right protection and predation behavior are mutually compatible.

\section{Predation and Public Policies}

We first characterize individual choices about predation, public decisions about property rights protection and fiscal policy conditional on the type of regime. In the following section we investigate the endogenous emergence of the political regime.

\footnotetext{
${ }^{12}$ As shown later, individuals belonging to the same group share the same preferences about political regimes and policies. Hence there is no need to model explicitly the aggregation of individual preferences leading to the choice of regimes and policies by part of the different groups. As far as political choices are concerned, in the following we therefore interchangeably refer to the group or individual preferences.
} 
Individual predation choice. The individually optimal predation strategy, denoted by $p_{t}^{i}$, maximizes expected disposable income, such that

$$
p_{t}^{i}=\arg \max _{p=\{0,1\}} x_{t}^{i} \text { s.t. } r_{t} \in\{\mathrm{o}, \mathrm{d}\}, \mathbf{y}_{t}, \mathbb{E}^{i}\left(c_{t}\right), \mathbf{p}_{t}^{-i},
$$

where $\mathbf{p}_{t}^{-i}$ denotes the vector of predation strategies adopted by all other individuals. The payoff of predation crucially depends on the enforcement of property rights and on the behavior of all other individuals. Public policies are implemented after individual predation investments, however. This implies that $p_{t}^{i}$ is conditional on the expectations concerning property rights enforcement $\mathbb{E}^{i}\left(c_{t}\right)$, and on the predation decisions taken by part of al the others, $\mathbf{p}_{t}^{-i} \cdot{ }^{13}$

Public Policies. The choice about property rights protection and redistribution is made by the politically enfranchised population in order to maximize their disposable income. Hence, the optimal strategy concerning property rights protection and fiscal schedule is given by,

$$
\left(c_{t}^{j}, f_{t}^{j}\right)=\arg \max _{c=\{0,1\}, f} x_{t}^{j}(c, f) \text { s.t. }\left\{\mathbf{p}_{t}, \mathbf{y}_{t}\right\},(6) \text {, and (9) where } j=\{E \text { if } r=\mathrm{o}, P \text { if } r=\mathrm{d}\} \text {. }
$$

Given the restrictions on the policy space, (6) and (9), the maximization of disposable income of the pivotal individual implies that under oligarchy the optimal fiscal policy stipulates maximal taxation of the disenfranchised people with transfer of the revenues, net of the costs of property rights protection, to the members of the elite. Under democracy, on the other hand, the optimal policy chosen by the pivotal voter, who is member of the people, implies the highest progressive redistribution possible i.e. full equalization of incomes. ${ }^{14}$ Notice that this is the case independently of the optimal strategy concerning $c_{t}^{j}$.

Public Policy Equilibria. In the absence of a possibility for commitment, the elite cannot credibly announce to abstain from expropriating the people under oligarchy. Similarly, under democracy, the only fiscal scheme that can be credibly announced implies full redistribution. These are the only rational expectations concerning $f_{t}$. To simplify exposition in the following we only refer to the strategy concerning the protection of property rights and omit explicit reference

\footnotetext{
${ }^{13}$ Since individuals are small with respect to the community, the expectations about aggregate outcomes do not depend on a particular individual's predation choices. The best strategy at the individual level therefore depends on public policies and income inequality. This is the case since both the after tax income $\widetilde{y}_{t}^{i}$ and the returns from predation are related to $\pi$. We rule out any possibility of coordination between agents in the choice of predation strategies. This reflects the view of predation choices being truly individualistic and not organized at the group level.

${ }^{14}$ As shown later, taxation involves distortions since it may induce agents to divert resources to predating activity thereby reducing fiscal collection.
} 
to the fiscal schedule. This can be done since there exists a one-to-one mapping between the political regime $r_{t}$ and the chosen fiscal schedule.

Public policies, which are constrained by the available public budget, are selected by the group with a majority in the enfranchised population in order to maximize the disposable income of its members. This is done after the realization of the taxable income i.e. after the predation choices, $\mathbf{p}_{t}$, have been made. In turn, these predation choices crucially depend on the (rational) expectations formed by the individuals about the public policies in equilibrium, as well as about the taxable income realized on the aggregate level. Consequently, a public policy equilibrium is defined as follows,

Definition 1. For any $r \in\{\mathrm{o}, \mathrm{d}\}$ and $\mathbf{y}_{t}$, the vector $\left\{\mathbf{p}_{t}(r), c_{t}(r)\right\}$ represents a public policy equilibrium if and only if:

i) predation choices are made optimally: $\mathbf{p}_{t}(r)=\left\{p_{t}^{i}\right\}_{\forall i}$ as defined in (13) given $\mathbb{E}^{i}\left(c_{t}\right)$;

ii) public policies are chosen optimally by the pivotal group: $c_{t}(r)=c_{t}^{j}$ satisfying (14); and

iii) implemented policies are consistent with expectations, $c_{t}(r)=\mathbb{E}^{i}\left(c_{t}\right)$.

Let us now investigate the equilibria which emerge under the different regimes. Under an oligarchy, the de jure political power is restricted to the elite. We now show that in the absence of the possibility to commit to fiscal policies, an oligarchic society is characterized by widespread predating activities that lead to a net loss in disposable income. This turns out to be the case since the people, anticipating extreme redistributive pressure by part of the oligarchic elite, optimally decide to predate. Consequently, property rights enforcement is infeasible ex-post. Under these conditions, the optimal strategy involves predation also by part of the members of the elite. ${ }^{15}$

Proposition 1. Under oligarchy, $r=\mathrm{o}$, for any $\mathbf{y}_{t}$ the public policy equilibrium is characterized by population-wide predation, $\left\{p_{t}^{i}(\mathrm{o})=1\right\}_{\forall i}$ and $\pi=1$, no property rights protection, $c_{t}(\mathrm{o})=$ $c_{t}^{E}=0$, and no tax revenues $T_{t}=0$ with $x_{t}^{i}=y_{t}^{i}(1-\varphi) \forall i$.

Proof. Since the elite cannot commit to limit the extent of regressive redistribution, any member of the people has a strictly dominant strategy to predate $p_{t}^{P}=1$ since this ensures a minimum disposable income of $y_{t}^{P}(1-\varphi)>0$. Notice that this is true irrespective of $\mathbb{E}^{P}\left(c_{t}\right)$ and regardless of the agent he is matched with. Consider now the elite. The only rational expectation involves

\footnotetext{
${ }^{15}$ Notice that the specification of fiscal policies (8) does not involve any limits to regressive redistribution, and therefore in principle allows for full expropriation. Essentially, the results are driven by the impossibility for the elite to commit to a sufficiently low level of regressive redistribution, as discussed below.
} 
$\mathbb{E}^{E}\left(c_{t}\right)=0$. Since under the anticipation that all the people necessarily predate, implying $\pi \geq(1-\gamma)>1 / 2$, property rights are not feasible from (6). In the predation game, if $i, j \in E$ are matched, then $p_{t}^{E}=1$ is a strictly dominant strategy. If $i \in E$ and $j \in P$ are matched, the richer player $i \in E$, might not have a dominant strategy $p_{t}^{E}$. This is the case if the gain from expropriating a landless $y_{t}^{P}$ is lower than the cost $\varphi y_{t}^{E}$. But since for $j \in P, p_{t}^{P}=1$ is a strictly dominant strategy then, by iterated deletion of strictly dominated strategies $p_{t}^{E}=1$ is optimal too. This implies $x_{t}^{i}=y_{t}^{i}(1-\varphi)$ for all $i$. Furthermore, $T_{t}=0$, and no public policies can be implemented so that from (14) $c_{t}=c_{t}^{E}=0=\mathbb{E}^{E}\left(c_{t}\right)$.

The only rational expectation is that property rights are not enforced under an oligarchy. This is the case since no commitment to public policies is possible. In spite of the fact that democracies are not assumed to be intrinsically superior in terms of the possibilities to commit to public policies, property rights can be enforced in equilibrium in democracies, however.

Proposition 2. Under democracy, $r=\mathrm{d}$, if $\mathbb{E}^{i}\left(c_{t}\right)=1 \forall i$, the public policy equilibrium is characterized by $c_{t}(\mathrm{~d})=c_{t}^{P}=1$. The corresponding predation choices are $\left\{p_{t}^{i}(\mathrm{~d})=0\right\}_{\forall i}$, with $\pi=0, T_{t}=y_{t}$ and $x_{t}^{i}=y_{t}$ for all $i$, if and only if

$$
y_{t}^{E}(1-\varphi) \leq y_{t}
$$

Alternatively, the predation choices are $\left\{p_{t}^{i}(\mathrm{~d})=0\right\}_{\forall i \in P},\left\{p_{t}^{i}(\mathrm{~d})=1\right\}_{\forall i \in E}$ with $\pi=\gamma, T_{t}=$ $y_{t}^{P}$ and $x_{t}^{P}=y_{t}^{P}, y_{t}^{E}=y_{t}^{E}(1-\varphi)$ if and only if

$$
y_{t}^{E}(1-\varphi)>y_{t}
$$

Proof. Under democracy with the people determining public policies, all individuals expect maximal progressive redistribution. Consider the expectation of public protection of property rights, $\mathbb{E}^{i}\left(c_{t}\right)=1 \forall i$. The expected payoff by not predating, $\widetilde{y}_{i}$, depends on predation by others $\mathbf{p}^{-i}$. The only rational expectation about the fraction of predators $\pi$ involves either $\pi=0$ or $\pi=\gamma$. To see this, consider a member of the people. By not predating he can insure himself a disposable income larger or equal to $y_{t}^{P}$ since the people decide about redistribution and are the poorest group of society. This implies that $p_{t}^{i}=0 \forall i \in P$ is a strictly dominant strategy. Consider now the rational expectation by part of $i \in E$. Since $p_{t}^{P}=0$, the maximum disposable income that $i \in E$ can earn by not predating is given by $\widetilde{y}_{t}^{E}=y_{t}$ which is realized only if $p_{t}^{i}=0$ for all $i \in E$. This payoff structure is depicted in Figure 2. Therefore if $y_{t}^{E}(1-\varphi) \leq y_{t}$ then $p_{t}^{E}=0$ is a strictly dominant strategy. In this case $\pi=0$. Alternatively if $y_{t}^{E}(1-\varphi)>y_{t}$, then 
$p_{t}^{E}=0$ is the strictly dominant strategy so that $\pi=\gamma$. This implies that initial expectations about $\pi$ are self-fulfilling. Finally notice that under both scenarios $c_{t}=c_{t}^{P}=1=\mathbb{E}^{i}\left(c_{t}\right)$ for all $i$ follows from (14).

Enforcing property rights in democracies is possible since the progressiveness of the fiscal policy is constrained by the no-ranking condition. ${ }^{16}$

The previous proposition reveals that democracies, even in the case when property rights are protected, may be characterized by different degrees of efficiency. Under condition (15), a democratic regime represents a strict Pareto improvement as compared to an oligarchy. In turn, predation still represents the best available option for the members of the elite under condition (16), even under democracy. Notice that Proposition 2 investigates under which conditions expectations regarding an effective public protection of property rights can be selffulfilling. But the results also show that an efficient use of productive resources, coupled with an effective enforcement of property rights, can be sustained in equilibrium only if expectations are appropriate.

Now consider the case in which public property rights are expected not to be enforced. Expectations about the absence of property rights enforcement, $\mathbb{E}^{i}\left(c_{t}\right)=0$, are always self-fulfilling no matter the political regime, economic inequality and the degree of inefficiency associated to predating activities.

Proposition 3. For any political regime $r$ and any $\mathbf{y}_{t}$, if $\mathbb{E}^{i}\left(c_{t}\right)=0$, the unique public policy equilibrium is characterized by population-wide predation, $\left\{p_{t}^{i}(r)=1\right\}_{\forall i}$ and $\pi=1$, no property rights protection, $c_{t}(r)=0, T_{t}=0$ and $x_{t}^{i}=y_{t}^{i}(1-\varphi)$ for all $i$.

Proof. Individual payoffs from predation are represented in Figure 1 . In this case $p_{t}^{P}=1$ is a strictly dominant strategy irrespective of the political regime. Also if both $i, j \in E$, then $p_{t}^{E}=1$ is a strictly dominant strategy. In turn if $i \in E$ and $j \in P$, then by iterated deletion of strictly dominated strategies $p_{t}^{E}=1$. This implies $\pi=1$ and from (14) $c_{t}^{j}=0$ for all $j \in\{E, P\}$.

The previous propositions characterize the full set of public policy equilibria. ${ }^{17}$ Notice also that for any $\mathbf{y}_{t}$ and given $\mathbb{E}^{i}\left(c_{t}\right)$ the equilibrium is unique. This implies that there is a one to

\footnotetext{
${ }^{16}$ This assumption, which is strongly supported by empirical observation, reflects the idea that the universal franchise in democracies is coupled with institutional mechanisms which protect the rights of minorities better than in oligarchies. This is in line with the common and empirically supported view that democratic institutions provide better constraints on the actions of governments.

${ }^{17}$ In any equilibrium individual policies and expectations must be mutually compatible. This implies that in any equilibrium it is either $\mathbb{E}^{i}\left(c_{t}\right)=0$ or $\mathbb{E}^{i}\left(c_{t}\right)=1$ for all $i$.
} 
one relationship between expectations about property enforcement and public policy equilibria.

\section{Politico-Economic Equilibria}

\subsection{Endogenous Political Regimes}

The political regime implemented during a given generation $t$ depends on the relative political power of the two groups and on their preferences about policies. The political regime is chosen by the group with larger de facto political power according to (11) and (12). This choice is made given the expectation concerning the emerging public policy equilibrium. The optimal strategy concerning the political regime is therefore given by,

$$
\begin{aligned}
r_{t}^{j}= & \arg \max _{\{\mathrm{o}, \mathrm{d}\}} x_{t}^{j}(r) \text { given } \mathbb{E}^{j}\left(c_{t}(r)\right) \text { where } j=\{E \text { if }(11), P \text { if }(12)\}, \\
\text { with } & r_{t}^{E}=\mathrm{o} \text { whenever } x_{t}^{E}(\mathrm{o})=x_{t}^{E}(\mathrm{~d}), \text { and } r_{t}^{P}=\mathrm{d} \text { whenever } x_{t}^{P}(\mathrm{o})=x_{t}^{P}(\mathrm{~d})
\end{aligned}
$$

Notice that in (17) we have assumed that each group chooses to be in power, i.e. to be pivotal in political decisions, whenever the disposable income of its members is the same under the two regimes. This natural tie-breaking assumption ensures a unique optimum.

For each generation $t$, the economy is in a Politico-Economic equilibrium (PE Equilibrium) if the choices of regime, public policies and predation are mutually compatible. Thus,

Definition 2. For any $\mathbf{y}_{t}$, the vector $\left\{\mathbf{p}_{t}^{*}, c_{t}^{*}, r_{t}^{*}\right\}$ represents a Politico-Economic (PE) Equilibrium if and only if:

i) the political regime is chosen optimally by the most powerful group: $r_{t}^{*}=r_{t}^{j}$ as in (17) given $\mathbb{E}^{j}\left(c_{t}(r)\right)$;

and, given the regime, public policies and individual predation choices represent a public policy equilibrium:

ii) $c_{t}^{*}=\mathbb{E}^{j}\left(c_{t}(r)\right)=c_{t}(r)$ as in Definition 1 ;

iii) $\mathbf{p}_{t}^{*}=\left\{p_{t}^{i *}\right\}_{\forall i}=\left\{p_{t}^{i}(r)\right\}_{\forall i}$ as in Definition 1 .

From Proposition 1 an oligarchic society is characterized by all agents getting involved in predating activities in the absence of property rights enforcement. We now investigate the conditions under which oligarchy is sustained as a PE Equilibrium. From Proposition 1 and 2 and given (17), the elite strictly prefers oligarchy whenever $y_{t}^{E}(1-\varphi)>y_{t}$, i.e. (16) holds. If the elite is sufficiently entrenched to impose their will, i.e. if (11) holds, then $r_{t}^{*}=r_{t}^{E}=0$. This is recorded in, 
Proposition 4 (Oligarchy). If (11) and (16) hold then the economy is characterized by a unique PE Equilibrium given by an oligarchy with population-wide predation activities and no property rights protection: $r_{t}^{*}=\mathrm{o}, p_{t}^{i *}=1 \forall i, c_{t}^{*}=0$.

In order to characterize the remaining $P E$ Equilibria, notice that the preferences of each individual regarding the political regime and predation choices depend on expectations about property rights enforcement. Concerning the members of the people, we have,

Lemma 1. The strategy profiles,

$$
\left\{\left(p_{t}^{P}, r_{t}^{P}\right) \mid \mathbb{E}^{P}\left(c_{t}\right)=1\right\}=\{0, \mathrm{~d}\} \text { and }\left\{\left(p_{t}^{P}, r_{t}^{P}\right) \mid \mathbb{E}^{P}\left(c_{t}\right)=0\right\}=\{1, \mathrm{~d}\}
$$

constitute strictly dominant strategies for each member of the people.

Proof. The people receive the lowest possible disposable income under oligarchy. Therefore, regardless of their expectations concerning property rights enforcement $\mathbb{E}^{P}\left(c_{t}\right)$, they would always choose to implement a democratic system. Consider now the expectation $\mathbb{E}^{P}\left(c_{t}\right)=1$. By not predating each member of the people rationally expects a disposable income larger or equal to $y_{t}^{P}$ which, in turn, is strictly greater than what he would expect by predating $y_{t}^{P}(1-\varphi)$. Thus $p_{t}^{P}=0$ whenever $\mathbb{E}^{P}\left(c_{t}\right)=1$. Alternatively, if $\mathbb{E}^{P}\left(c_{t}\right)=0, p_{t}^{P}=1$ represents a strictly dominant strategy as shown in Figure 1.

This Lemma implies that for the people implementing a democracy is always a strictly dominant strategy regardless of the expectations concerning the possibility that property rights are implemented in equilibrium. Expectations about property rights enforcement only affect individual predation choices.

Consider the case in which the elite prefers oligarchy, i.e. condition (16) holds, but at the same time the elite is not powerful enough to implement its favorite regime, i.e. condition (12) holds. Under this condition, the choice of the political regime mirrors the preferences of the people. As consequence of Lemma 1 a democratic political regime is implemented regardless of the expectations of the people concerning the enforcement of property rights. From Proposition 2 and 3 the PE Equilibrium can be characterized under these conditions by two different scenarios that imply different economic outcomes.

Proposition 5 (Conflictual Democratization). If (12) and (16) hold then the economy is characterized by a democratic PE Equilibrium with $r_{t}^{*}=\mathrm{d}$, and:

i) population-wide predation, $p_{t}^{i *}=1 \forall i$ and no property rights enforcement $c_{t}^{*}=0$ if $\mathbb{E}^{i}\left(c_{t}(\mathrm{~d})\right)=0$ for all $i$ 
ii) intermediate predation and property rights enforcement, $p_{t}^{i *}=0 \forall i \in P, p_{t}^{i *}=1 \forall i \in E$ and $c_{t}^{*}=1$ if $\mathbb{E}^{i}\left(c_{t}(\mathrm{~d})\right)=1$ for all $i$.

In other words, the previous proposition states implementation of a democratic regime under the pressure of the disenfranchised people leads to a democracy which is denoted conflictual, since it does not represent a strict Pareto improvement with respect to an oligarchy. ${ }^{18}$ Under these conditions, even in the case in which property rights are enforced in equilibrium, it is not possible to induce the elite to abstain from protecting themselves by predation. The system is characterized by widespread predation activities in the absence of property rights enforcement unless all individuals in society expect property rights to be enforced ex-post. The proposition also implies the emergence of multiple $P R$ Equilibria depending on the expectations about property rights enforcement.

Notice, however, that from Proposition 2 a democratic transition can also imply a strict Pareto improvement. This is the case when the implementation of property rights protection in democracy effectively discourages investments in predation. However, this is possible only if (15) holds, i.e. if $y_{t}^{E}(1-\varphi)<y_{t}$. Under these conditions the elite may prefer a democracy even when they are sufficiently entrenched to implement an oligarchy. ${ }^{19}$ This condition is not sufficient, however, to ensure the emergence of a democracy in which property rights are enforced and no resources are wasted in predation. In fact, in addition it is required that all individuals in the economy have mutually consistent expectations that widespread predating behavior will not arise in equilibrium and property rights will therefore be enforced. From Proposition 3, "pessimistic" expectations, $\mathbb{E}^{E}\left(c_{t}\right)=0$, are self fulfilling and no public property rights protection would materialize in a democracy that is characterized by widespread predating behavior.

Depending on their expectations about property rights enforcement, the optimal strategy for members of the elite is either to make a democratic offer or to implement an oligarchic regime.

Lemma 2. If (11) and (15) hold, then for the each member of the elite the strategy profiles

$$
\left\{\left(p_{t}^{E}, r_{t}^{E}\right) \mid \mathbb{E}^{E}\left(c_{t}\right)=1\right\}=\{0, \mathrm{~d}\} \text { and }\left\{\left(p_{t}^{E}, r_{t}^{E}\right) \mid \mathbb{E}^{E}\left(c_{t}\right)=0\right\}=\{1, \mathrm{o}\}
$$

are strictly dominant strategies.

Proof. As shown in Proposition 2, whenever condition (15) holds and if $\mathbb{E}^{E}\left(c_{t}\right)=1$, then under democracy each member of the elite optimally decides not to predate and obtains a disposable

\footnotetext{
${ }^{18}$ This is in line with the view of democratization under the threat of social conflict proposed by Acemoglu and Robinson (2000, 2001, 2005), and Acemoglu, Johnson, and Robinson (2005).

${ }^{19}$ This argument is in line with the one proposed by Lizzeri and Persico (2004) about the democratization process in England during the 'Age of Reforms'.
} 
income equal to $y_{t}$. This disposable income is, in turn, strictly greater than any income that could be obtained under oligarchy, $y_{t}^{E}(1-\varphi)$. Consider now the expectation $\mathbb{E}^{E}\left(c_{t}\right)=0$. In this case, as shown in Proposition $3, p_{t}^{E}=1$ represents a strictly dominant strategy independently of the political regime in place. Under these condition from (17) then $r_{t}^{E}=\mathrm{o}$.

Therefore, the economy always faces a coordination dilemma, even when a democracy implementing an efficient system of property rights protection is feasible.

In order to investigate which PE Equilibrium emerges under these conditions recall the different stages of the politico-economic game. In the first stage, the group with larger de facto political power implements a political regime, and then all individuals of both groups play a predation/policy game. This implies that all individuals observe the regime implementation before making the predation choices in the second stage. Following Lemma 2, the optimal strategy of the elite implies that democratization is optimal only if they expect property rights to be enforced. Hence the observation by part of the people of a democratic transition offered by an entrenched elite reveals that $\mathbb{E}^{E}\left(c_{t}\right)=1$ and that $p_{t}^{E}=0$, accordingly. This is the case since if $\mathbb{E}^{E}\left(c_{t}\right)=0$ the elite would have implemented an oligarchy. In turn, since $p_{t}^{E}=0$ the optimal strategy for the people involves no predation as well: $p_{t}^{P}=0$. Therefore, solving the game by forward induction, the elite makes a democratic offer in the first stage under the anticipation that democratization represents a signal of their expectations $\mathbb{E}^{E}\left(c_{t}\right)=1 .^{20}$ As a consequence, if conditions (11) and (15) hold the elite will make a democratic offer and an efficient democracy will emerge. The arising democracy is labelled consensual because it implies a Pareto improvement and is therefore supported by a consensus of all groups of society.

Proposition 6 (Consensual democratization). If (11) and (15) hold, then the unique PE Equilibrium is characterized by a democracy with property rights enforcement and no predation: $r_{t}^{*}=r_{t}^{E}=\mathrm{d}, c_{t}^{*}=c_{t}^{E}=1$ and $p_{t}^{i *}=0$ for all $i$.

While a consensual democratization can solve the coordination problem, this is not possible with a conflictual democratization. There, the multiplicity cannot be ruled out by applying an equilibrium refinement based on reasonable beliefs and forward induction since the observation that the people implement a democratic regime does not convey any relevant information about their beliefs as consequence of Lemma $1 .^{21}$

\footnotetext{
${ }^{20}$ The use of forward induction argument as a refinement criterion in the presence of multiple equilibria was proposed by Kohlberg and Mertens (1986) and Kohlberg (1989). Notice that in the pure coordination game of the present context, the elite has nothing to gain from inducing the wrong expectations.

${ }^{21}$ As anticipated above, despite the role of expectations, preferences about political regime and policies are the
} 
It is noteworthy that the allocation of de facto political power plays different roles in the different types of democratic transitions. A consensual democratization leads to a strict Pareto improvement for members of all groups in society. Under the corresponding conditions democracy can be sustained independently of the allocation of de facto political power. This is not the case after a conflictual democratization where the people enforce the extension of the franchise against the will of the ruling class. In fact, under the conditions of a conflictual democracy, the elite would rather implement an oligarchy. This implies that whenever democracy does not represent a Pareto improvement a change in the allocation of the de facto political power leads to a change of regime, making the conflictual democracy intrinsically more unstable. Consequently, the type of democratization has profound implications for both the efficiency and the stability features of the emerging democracy.

Discussion. Before proceeding with the investigation of the taxonomy for the democratic transition some remarks are in place. Several specific assumptions were made for analytical tractability. The timing assumed that predation choices take place after factor income is produced. Alternatively one could consider predation investments to take place before production. In this case the absence of property rights protection would further reduce income production and growth by discouraging productive investments (like human capital formation).

A more general functional specification of $G(\pi)$ would imply that, under some conditions, either the elite (under oligarchy) or the people (under democracy) may be able to implement property rights protection which they finance entirely by themselves. The only advantage of property rights implementation in these equilibria is to allow the group in power to save on predation costs. Apart from making the presentation more involved this would leave all qualitative results unchanged, including the prediction that consensual democracies are the most efficient outcome. This is the case, because, measuring efficiency in terms of total disposable income in the economy, in any other equilibrium strictly larger predation investments and cost of property rights protection arise.

The cost of predation $\varphi$ was assumed to be identical across regimes and independent of the allocation of political power. Assuming a larger $\varphi$ under democracy, implying that democracies are inherently better in protecting property rights, would facilitate the adoption of democracy same for individuals of the same type for any $\mathbf{y}_{t}$. Expectations do not affect public policies, which are chosen optimally after predation has taken place. Also, no coordination problem arises at the moment of choosing the regime. From Lemma 1 each member of the people always prefers democracy to oligarchy. From Proposition 4 and Proposition 6 the preferred regime of the members of the elite only depends on condition (15). 
and imply that conflictual democracies, even in the worst scenario, lead to better economic outcomes than oligarchies. Alternatively, if $\varphi$ were related to the control of de jure power, for example through the control over police forces or army, this would provide a further incentive to retain political power. Under this scenario, being in power delivers an additional advantage whenever property rights are not expected to be implementable.

Furthermore, the model implies that, differently from oligarchies, democracies can successfully implement public property rights protection. Notice that this result does not depend on any assumed differential ability to commit to property rights protection by part of different social groups or under different political regimes. The only difference between the two systems is the identity of the pivotal agent and, consequently, the fiscal schedule in equilibrium. Clearly an exogenous differential ability to commit to property rights would make property rights protection more likely in equilibrium. ${ }^{22}$

\subsection{Taxonomy of Democratic Transitions}

The emergence of the different equilibria described in the previous subsection crucially depends on inequality and on the efficiency cost of predating activities. Denote the relative (per capita) income of the elite and the people as

$$
\lambda_{t} \equiv \frac{y_{t}^{E}}{y_{t}^{P}} .
$$

For any $\lambda_{t}$, and thus for any generation $t$, only one of the PE Equilibria characterized in Propositions 4,5 and 6 can emerge.

From the substitutability between $H$ and $N$ as factors of production in the production process (1), Inada conditions, and the fact that the technological level is increasing overtime as consequence of (3), it follows that the rents on natural resources decrease during the process of development, so that $\partial \rho_{t} / \partial A_{t}<0$ and $\lim _{A \rightarrow \infty} \rho_{t}=0 .{ }^{23}$ This implies that, in the limit, the share of income produced by, and distributed to the owners of, natural resources converges to zero, unlike the shares of income produced by labor and human capital. As a result, income inequality decreases over time and vanishes in the limit. ${ }^{24}$

\footnotetext{
${ }^{22}$ For example, if a dictator managed to commit to public policies, efficient economic outcomes could be more easily realized under oligarchy. In fact, Glaeser et al. (2004) provide examples of oligarchic governments that created environments in which property rights are protected.

${ }^{23}$ For example, in the case of the previously cited production function $Y_{t}=\left(A_{t} H_{t}+N\right)^{\alpha}\left(L_{t}\right)^{1-\alpha}$, with $0<\alpha<1$, the rents on natural resources, are given by $\rho_{t}=\alpha\left(A_{t} H_{t}+N\right)^{\alpha-1} L^{1-\alpha}$.

${ }^{24}$ As will become clear below, the main results of the model do not depend on the monotonous decline in inequality that is driven by the assumptions on the evolution of technology. These assumptions are merely chosen for illustrative reasons.
} 
Lemma 3. Income inequality $\lambda_{t}$ decreases monotonically overtime with $\lim _{t \rightarrow \infty} \lambda_{t}=1$.

For illustrative purposes, we begin the analysis of the model dynamics by considering a situation in which the rents to natural resources, and therefore income inequality, are sufficiently large so that the elite dominates in terms of political power. ${ }^{25}$ Under these initial conditions both (11) and (16) hold, and the economy is characterized by an oligarchic politico-economic equilibrium. The subsequent reduction of inequality eventually leads to a democratic transition of one of the two types discussed before. Both conditions (16) and (11), under which the elite prefers an oligarchic regime and is sufficiently entrenched to impose its will, respectively, eventually cease to hold as consequence of Lemma 3. On the one hand, the reduction of inequality eventually makes the cost of redistribution associated with a democratic transition smaller than the cost of predation. On the other hand, the elite, which represents a minority in the population, eventually loses de facto political power. This implies the following,

Lemma 4. For any $\left\{\gamma, n, A_{0}\right\}$, there exist threshold generations $\left\{\bar{t}\left(\gamma, n, A_{0}\right), \underline{t}\left(\gamma, n, A_{0}\right)\right\}$ for the different types of democratic transitions, such that:

i) Condition (16) holds only if $t<\bar{t}\left(\gamma, n, A_{0}\right)$;

ii) Condition (11) holds only if $t<\underline{t}\left(\gamma, n, A_{0}\right)$.

From Propositions 5 and 6 it follows that whenever $\underline{t} \leq \bar{t}$, the economy experiences a conflictual democratic transition enforced by the people. Conversely, whenever $\underline{t}>\bar{t}$, we observe a consensual democratic transition voluntarily offered by the elite.

We now investigate under which conditions either the first or the second kind of transition will arise. The dynamic evolution of the economic system and the endogenous emergence of the different equilibria can be fully characterized by the conditions that reflect the preferences of the elite regarding the political regime, and the allocation of de facto political power, both in terms of $\gamma$ and $\lambda$. The elite is assumed to be smaller and initially richer than the people. This implies that the values of inequality defining the subset of the $\{\gamma, \lambda\}$-space relevant for the analysis are given by $\gamma \in[0,1 / 2)$ and $\lambda \geq 1$.

The locus of combinations $(\gamma, \lambda)$ for which the two groups have the same de facto political power, i.e. condition (11) holds with equality, is given by,

$$
\lambda=\Gamma(\gamma)=\frac{1-\gamma}{\gamma}
$$

\footnotetext{
${ }^{25}$ These initial conditions require a sufficiently underdeveloped economy with the initial level of productivity $A_{0}$ sufficiently small.
} 
This locus $\Gamma(\gamma)$ delivers a unique critical level of $\lambda$ for each $\gamma$. In the $(\gamma, \lambda)$-space, the locus is downward sloping since an increase in the size of the elite $\gamma$ must be compensated by a reduction of its per capita income, and thus $\lambda$, to keep the de facto political power balanced.

In turn, the combinations of $(\gamma, \lambda)$ for which condition (15) holds with equality and the elite receives the same income under both political systems, are given by,

$$
\lambda=\Upsilon(\gamma, \varphi)=\frac{1-\gamma}{1-\gamma-\varphi}
$$

The locus $\Upsilon(\gamma, \varphi)$ is upward sloping in the $(\gamma, \lambda)$-space. A larger $\gamma$ implies a smaller group of people and, for any given $\lambda$, a higher per capita income $y$. Consequently, a larger $\gamma$ implies that democratization is less costly in terms of redistribution, leading to a larger level of income inequality $\lambda$ for which the elite receives the same income under the two regimes.

These results imply a taxonomy of democratic transitions as function of exogenous parameters. The smaller the elite, i.e. the smaller $\gamma$, the larger the concentration of the ownership of natural resources and consequently the inequality in the distribution of their rents. From the discussion of the two loci and the implied transitions, we can derive the following

Proposition 7. For any $\left\{\gamma, n, A_{0}\right\}$ and $\varphi$ there exists a threshold in the concentration of natural resource ownership given by $\widetilde{\gamma}(\varphi)=(1-\varphi) / 2$ such that

$$
\gamma \gtrless \widetilde{\gamma}(\varphi) \Longleftrightarrow \bar{t}\left(\gamma, n, A_{0}\right) \lessgtr \underline{t}\left(\gamma, n, A_{0}\right)
$$

i.e. consensual democratic transitions arise for lower concentration with $\gamma>\tilde{\gamma}$, while conflictual democratic transitions arise for larger levels of inequality in resource ownership, $\gamma<\tilde{\gamma}$.

Proof. The locus $\Gamma(\gamma)$ is strictly decreasing and convex with $\Gamma(0)=\infty$ and $\Gamma(1 / 2)=1$. The locus $\Upsilon(\gamma, \varphi)$ is upwards sloping and convex in $\gamma$ with $\Upsilon(0, \varphi)=1 /(1-\varphi)>1$ and exhibits a vertical asymptote at $\hat{\gamma}(\varphi)=1-\varphi$ (with negative values of $\Upsilon(\cdot)$ for $\gamma>\hat{\gamma}(\varphi)$ ). This implies that there exists a unique level of initial concentration in the distribution of natural resources denoted by $\widetilde{\gamma}(\varphi)$ for which the two loci intersect. For any $\gamma<\widetilde{\gamma}(\varphi)$ the locus $\Gamma(\gamma)$ lies above $\Upsilon(\gamma, \varphi)$ while the opposite is true for any $\gamma>\widetilde{\gamma}(\varphi)$. The conditions of the economy during the life of any generation $t$ are therefore fully characterized by the pair $\gamma$ and $\lambda_{t}$. Note that since $\gamma$ is unchanged overtime, development occurs on a vertical trajectory in the $\{\gamma, \lambda\}$ space. The sequence of PE Equilibria depends on the initial conditions in terms of concentration in the distribution of natural resources and on the distortions associated to predation. This discussion together with Lemma 3 proves the statement. ${ }^{26}$

\footnotetext{
${ }^{26}$ Notice that if $\varphi>1 / 2 \Rightarrow \hat{\gamma}(\varphi)<1 / 2$. In this case for any $\gamma \in[\hat{\gamma}(\varphi), 1 / 2]$ the conditions for consensual
} 
Figure 3: An Illustration of the Transition Thresholds

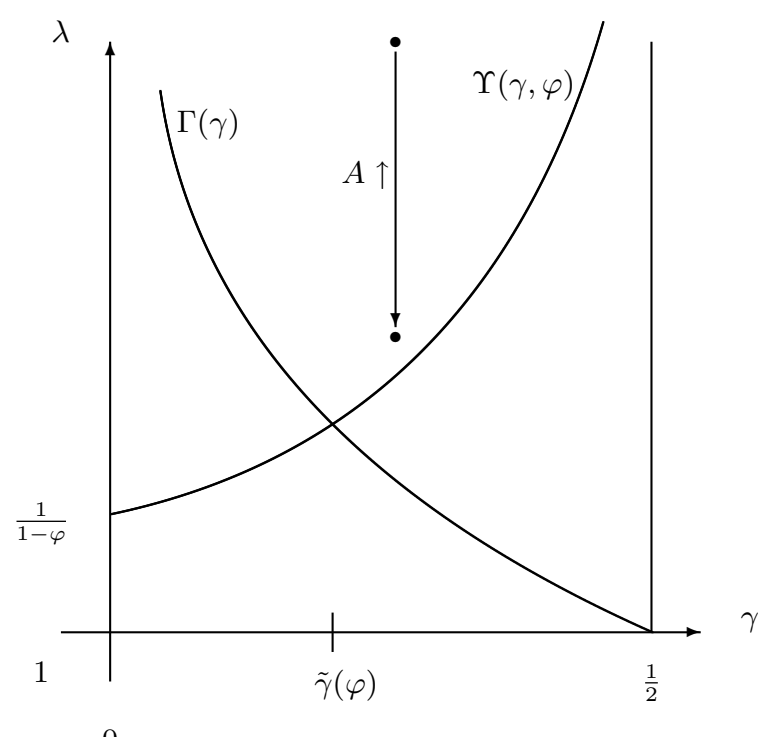

0

Figure 3 illustrates the two loci and the intuition behind Proposition 7. For levels of $\lambda$ above the two loci, the elite prefers an Oligarchic regime and it is sufficiently entrenched to enforce its preferences. Hence, this area reflects the combinations of $\gamma$ and $\lambda$ for which the economy is characterized by an oligarchic PE Equilibrium. In the area below the $\Upsilon$ locus a consensual democracy emerges, while in the area below the $\Gamma$ locus democratization would be conflictual. The proposition states that for a consensual democracy to arise the concentration in the ownership of natural resources must not be too large. Intuitively, if the resource ownership is too concentrated, i.e. if $\gamma$ is too small, then the cost of democratization in terms of redistribution is prohibitively large for the elite. Nevertheless, the elite eventually finds it profitable to voluntarily offer democratization, but only for very low levels of income inequality. Under these conditions, the group of people gains de facto political power already before, at larger levels of income inequality $\lambda$. In light of the process of development these considerations jointly imply a conflictual democratization as the only feasible scenario under these conditions.

The graphical analysis of the taxonomy also reveals that the progressive reduction of inequality implies that the conditions for a consensual democracy are eventually satisfied for any $\gamma$. However, this does not imply that the problem of coordinating expectations about the possibility of implementing property rights protection can be solved when conflictual democracies

democracies would always be fulfilled so that $\bar{t}\left(\gamma, n, A_{0}\right)=0$ for all $n, A_{0}$. This is the case since the cost associated to the predation activity under oligarchy is too large. 
are already in place. This is the case since, once a democracy is established, neither the elite nor the people can signal their expectations about property rights. In this context, the model generates history dependence. Countries that initially democratized conflictually may fail to implement efficient economic policies even when they are eventually feasible.

Finally notice that the model predicts an endogenous dynamic perpetuation of the initial level of inequality through the economic policies and outcomes that it generates. Unequal societies are more likely to lead to conflictual democracies in which, given the widespread waste of predation and the limited room for fiscal redistribution, income inequality remains large. The opposite is true for consensual democratic transitions, which occur in more equal societies and induce a further reduction in income inequality through the redistribution schemes they entail. ${ }^{27}$

\section{$5 \quad$ Predictions and existing evidence}

The model predicts that different types of transitions to democracy can arise. These transitions are related to inequality and affect the economic policies as well as the subsequent development path under the newly established democratic structures. In this section we briefly discuss the implications of the model and argue that they are broadly in line with the existing empirical evidence.

Determinants of Democratic Transitions. The paper relates to the ongoing debate on the determinants of democratization. Several authors, including Przeworski and Limongi (1997), Barro (1999), and Przeworski et al. (2000), among others, have found evidence for a positive effect of income per capita on the emergence and prevalence of democratic structures. However, the recent findings of Przeworski (2004) and Acemoglu et al. (2005) cast doubt on the existence of a direct causal effect and highlight the role of historical factors for democracy. Evidence reported by Easterly (2001), Boix and Stokes (2003) and Boix (2003), among others, suggests that the level of income per capita potentially only plays an instrumental role for political change and democratization, while inequality constitutes a more relevant determinant. ${ }^{28}$ Likewise, Glaeser et al. (2006) provide evidence for the crucial role of widespread education for the emergence

\footnotetext{
${ }^{27}$ This is supported by the data as discussed in section 6 below.

${ }^{28}$ In particular, Boix and Stokes (2003) show that the economic prosperity goes hand in hand with the availability of human capital, the portion of farmers in the population, and the degree of occupational diversification. The latter variable is indeed a measure of the degree of industrialization while the first two capture the reduction in income inequality. Their results suggest that both the reduction of inequality and the degree of industrialization substantially increase the probability of a transition to democratic regimes. Barro (1999) also finds a positive effect of equality in terms of the income share of the middle class on the propensity of democracy.
} 
and stability of democracy.

The process of democratization in the model presented above is primarily driven by economic development and changes in the distribution of incomes, resulting from changing importance of the different factors of production. The actual underlying determinant is economic inequality and the relative importance of human capital as factor of production. The instrumental role of development, and the importance of inequality in the control over economic resources, for the emergence of democracy is overall in line with the empirical findings.

Different Types of Democratic Transitions. From a historical point of view, there are a number of examples that suggest the existence of different transition paths towards democracy which lead to different institutional outcomes and economic policies. If the elite is unwilling to give away political power, which is the case if democracy mainly harms them, but the people become stronger and revolt, conflictual transitions occur. Conceptually, conflictual democratic transitions are triggered by a threat of conflict against the elite, possibly reflected in open conflict and revolution. In this context, democratic reforms may be enforced. Historically, many regime changes resulted from the uprising of a politically (and economically) deprived class. The threat of revolution and social unrest, for example, often played an essential role in the establishment of voting rights for the disenfranchised people in many Latin American countries. ${ }^{29}$

Consensual democratic transitions, on the other hand, exhibit changes in the political regime that are accepted or even actively promoted by the elite. In particular, all historical episodes of democratic transitions that occurred in the absence of a serious threat fall into the category of consensual democratization. In line with our model, Huber et al. (1993) argue that capitalist development reduced the importance of land resources, and therefore eroded the empirical and political power of the landlord class. If the members of the elite have strong economic interests in new technologies and efficiency, and at the same time are not entirely dependent on the returns from natural resources, it is more likely that they voluntary induce franchise extensions which are reflected by consensual transitions in our model. Historical examples for consensual transitions include the Nordic countries. ${ }^{30}$ Notice, however, that episodes in which the democratic transition was ultimately in the interest of the ruling class fall into the category of consensual democratization, even in the presence of social unrest and conflictual threat by

\footnotetext{
${ }^{29}$ Examples for democratic transitions under a shadow of conflict between richer and poorer parts of society are Uruguay (1919), Colombia (1936), Venezuela (1945) and Nicaragua (1979). See also, Acemoglu and Robinson (2005, ch. 2). In the terminology of this paper, all these cases would fall under the category of conflictual democratization.

${ }^{30}$ For example, Llavador and Oxoby (2005, page 1182) note that "there is no evidence in the Danish case of a government forced to offer expansions of the suffrage against its will."
} 
part of the disenfranchised as long as this threat was not the trigger for the transition. In some cases it is not obvious to understand whether the threat to revolt was binding at the moment of democratization. This makes the classification of a transition process non-trivial in some cases. In the case of Britain, for example, Acemoglu and Robinson (2000) emphasize the existence of a latent conflict and pressure to extend the franchise. In subsequent work Lizzeri and Persico (2004) and Llavador and Oxoby (2005) argue, however, that an extension of the franchise was in the interest of, and promoted by, a large part of the elite. ${ }^{31}$ According to this interpretation, democratization in Britain would be considered as consensual. ${ }^{32}$

Economic Consequences of Democratic Transitions. The theory predicts that democracies do not necessarily lead to the emergence of efficient economic systems, but under certain circumstances, when it is consensual, a democratic transition can serve to implement an equilibrium without predation. These predictions relate to the empirical debate about the causal role of democracy for economic development. Recent work by Tavares and Wacziarg (2001), Papaioannou and Siouraounis (2004) and Rodrik and Wacziarg (2005) has provided evidence for positive effects of democracy or democratization on growth. In contrast, Barro (2000) and Glaeser et al. (2004) find no evidence for a direct causal effect of democracy on growth. The predictions of our model imply that democratization is not sufficient to guarantee the achievement of efficient outcomes. However, democratization can affect development indirectly through the adoption of better economic policies, like property rights protection and a rule of law. This view is supported by the empirical findings of Acemoglu et al. (2001) Rigobon and Rodrik (2004), and Rodrik et al. (2004), among others.

\section{Empirical Evidence}

In this section we provide some empirical evidence for the relevance of the novel predictions using cross-country data.

Resource Inequality and Property Rights. The model predicts a link between the process of democratization, the quality of economic policies, the extent of predation and rentseeking activities. From Propositions 5 and 6 and the discussion of the taxonomy, an environment

\footnotetext{
${ }^{31}$ Lizzeri and Persico (2004) document that the members of the elite were aware of the advantages of extending democracy. Llavador and Oxoby (2005) argue that large parts of the elite strategically promoted an extension of the franchise in order to reap economic benefits.

${ }^{32}$ This view is also consistent with the arguments put forward by Justman and Gradstein (1999) who provide similar explanations for the role of economic development, as exemplified by the industrial revolution in Britain, for democratization and subsequent declines in economic and political inequality.
} 
with lower predation and better protection of property rights is expected to emerge in consensual democracies, which in turn arise only if the concentration in the ownership of natural resources is sufficiently low.

To reflect the presence of predation or absence of property rights, we use measures of rule of law from different data sources. The World Bank provides measures of the quality of institutions and governance, collected by Kaufmann et al. (1999a, 1999b). In light of our theory, the point estimates of the fifth cluster (rule of law) appear most relevant. ${ }^{33}$ The International Country Risk Guide (ICRG) provides alternative measures reflecting the presence of rule of law. ${ }^{34}$ The crucial institutional distinction between democracies and oligarchies in the theoretical model, apart from the extent of the franchise, concerns the different restrictions on the fiscal policy space. Under democracy, redistribution is limited and does not allow for full expropriation of part of society, while this is possible under oligarchy. As variable reflecting this distinction we can use a measure of the protection against expropriation by the state or the political class in power. ${ }^{35}$ Finally, to discriminate between the role of inequality for the enforcement of property rights and for political stability, we use the second cluster (political stability) of measures of the quality of institutions and governance, collected by Kaufmann et al. (1999a, 1999b). ${ }^{36}$

Concerning initial inequality in resource endowments a naive approach is to use inequality today as proxy for inequality at the time of transition, arguing that the model predicts a perpetuation and persistence of inequality: only more equal countries can be expected to adopt

\footnotetext{
${ }^{33}$ Kaufmann et al. (2004, p. 4) describe the "rule of law" cluster as including "several indicators which measure the extent to which agents have confidence in and abide by the rules of society. These include perceptions of the incidence of crime, the effectiveness and predictability of the judiciary, and the enforceability of contracts. Together, these indicators measure the success of a society in developing an environment in which fair and predictable rules form the basis for economic and social interactions, and importantly, the extent to which property rights are protected." The measure is standardized.

${ }^{34}$ The variable "rule of law" reflects the degree to which the citizens of a country are willing to accept the established institutions to make and implement laws and adjudicate disputes on a scale from 0 to 10 . Lower scores indicate a tradition of depending on physical force or illegal means to settle claims. The variable is generated from monthly data collected for the ICRG, see Knack and Keefer (1997) for a description. Data used here are averages for the years 1985-1995.

${ }^{35}$ The variable "protection against risk of expropriation" evaluates the risk of outright confiscation and forced nationalization of property on a scale from 0 to 10 with lower ratings describing countries where expropriation of private investment is a likely event. The data source is the same as in footnote 34 .

${ }^{36}$ The "political stability and absence of violence" cluster combines "several indicators which measure perceptions of the likelihood that the government in power will be destabilized or overthrown by possibly unconstitutional and/or violent means, including domestic violence and terrorism" Kaufmann et al. (2004, p. 3). The measure is standardized.
} 
consensual democracies in which large scale redistribution can be implemented and leads to a further reduction in inequality. In fact, previous empirical findings indicate that historical inequality generally is a good predictor of inequality today. ${ }^{37}$ In the empirical analysis we use Easterly's (2001) middle class income share, measured by the relative size of the three middle income quintiles averaged over the years 1960-1996, as measure of equality. Invoking the argument by Engerman and Sokoloff (1997, 2001) and Easterly (2001) a measure of tropical location, reflected by an indicator of an average latitude of less than 23.5 degrees, could also serve as proxy for resource inequality. According to this argument, tropical location favors production of agricultural products and commodities in large estates, which in turn lead to an unequal distribution of natural resources in the population.

Table 1 presents the results for the institutional quality outcome for OLS regressions with inequality, latitude, ethnic fragmentation and including a dummy for commodity and for oil exporting as explanatory variables. ${ }^{38}$ Equality in terms of the middle class share is the strongest predictor of institutional quality. Tropical location, commodity exporting and oil exporting play a smaller role, and are not significant for some of the institutional measures. This provides some first indication for the relevance of the theoretical prediction that inequality plays a crucial role for the adoption of good institutions.

However, these results may suffer from a severe endogeneity problem if institutions affect inequality, or if other variables that are not contained in the specification are correlated both with inequality and institutional quality. In light of our theory, a primary candidate for this is the existence of a democracy. To investigate this conjecture, we add a dummy that takes value 1 for countries viewed as democratic and contained in the study by Persson and Tabellini (2004), as additional explanatory variable. ${ }^{39}$ In fact, it turns out that the prevalence of democracy has a significant positive effect on the quality of institutions as measured in columns (1) and (3), but not in columns (2) and (4). ${ }^{40}$ The effects of inequality measured by the middle class income

\footnotetext{
${ }^{37}$ Lindert (2000) provides evidence that inequality in England and the U.S. in 1995 was roughly at the same levels as in the seventeenth century. Similar patterns seem to apply to other countries, see Lindert and Williamson (2003). Easterly (2005) uses family farm data to show that inequality in the mid 19th century predicts inequality today.

${ }^{38}$ We add the latter variables since they are used by Easterly (2001) to facilitate the comparison. Excluding these variables leaves the main results qualitatively unaltered.

${ }^{39}$ The democracy dummy indicates countries viewed as democratic and contained in the study by Persson and Tabellini (2004). Following Persson and Tabellini (2004), a country is coded as democratic if the Freedom House indices of political rights and civil liberties (Gastil), which range from 1 to 7 with lower values indicating better democratic institutions, do not exceed 5 on average between 1990 and 1998 .

${ }^{40}$ Detailed results are available upon request.
} 
share are virtually unaffected by adding a dummy for democracy. More importantly, however, the theoretical model implies that both economic policies as well as political institutions should be treated as endogenous. On top of that, given the theory both might affect the middle class income share as well as each other.

To circumvent this problem, we adopt a more structural approach building on the link between geographical features, the type of natural resources they imply, and inequality. Easterly (2001) tests this link first proposed by Engerman and Sokoloff $(1997,2001)$ by showing that tropical endowment leads to a higher propensity of commodity production, which in turn is associated with higher inequality. ${ }^{41}$ Applying this strategy to cross-country data for the 1990s, Easterly instruments the middle class income share as measure of equality. His estimates show that equality in the form of a large economic importance of the middle class has a large and significant positive effect on income per capita and on income growth. ${ }^{42}$ Easterly and Levine (2003) compare different alternative instrumentation strategies. Their results provide further evidence that tropical location has no direct effects on economic development other than through institutions, lending additional support to the validity of the instrumentation strategy. ${ }^{43}$ In the following, we adopt the approach suggested by Easterly (2001) to provide a more direct test of the theory by applying instrumented measures of resource and income inequality in regressions of the quality of institutions as outcomes. ${ }^{44}$

The taxonomy of democratic transitions relates to inequality in resource endowments and consequently inequality in disposable incomes. Arguably, the application of Easterly's instrumentation strategy in the current context is even more appropriate as inequality needs to be instrumented at the point at which an observed regime is established, rather than at present. Inequality at transition should thus be at least as strongly affected by inequality in endowments with natural resources as inequality today. ${ }^{45}$ Moreover, as mentioned before, the model provides

\footnotetext{
${ }^{41}$ In his data, a commodity exporting dummy is generated using an indicator established by the World Bank.

${ }^{42}$ Apart from the effects of equality on outcomes like per capita income levels and income growth, Easterly presents results for the effect of equality on variables reflecting the quality of economic policies, democracy, and political stability. In particular, he finds that more unequal countries exhibit less widespread political rights and more suppression of civil liberties, and therefore tend to be characterized by less democratic institutions, or democratic institutions of lower quality.

${ }^{43}$ Easterly (2005) presents additional evidence for the Engerman-Sokoloff-hypothesis using a measure of the relative share of land suitable for sugar cane production as instrument for inequality in factor endowments.

${ }^{44} \mathrm{We}$ adopt this approach since it is well suited to test our theory which is not confined to former colonies or developing countries only.

${ }^{45}$ At the same time, in the current context it appears unlikely that tropical endowment and commodity exporting has a direct effect on outcomes of interest below other than through inequality. The results in Table 1 show that tropical location and commodity exporting have weak direct effects on the central outcome variables. This issue
} 
a rationale for the perpetuation of inequality. More equal countries are more likely to democratize in a consensual way, which in turn leads to the adoption of larger redistribution than in conflictual democracies. Hence, the model provides theoretical support for the instrumentation strategy based on initial inequality instrumented by tropical location and middle class income shares. Consequently, we instrument the middle class share and use the instrumented value, together with a measure of ethnic fragmentation, to explain different measures of the quality of property rights protection. ${ }^{46}$

The results of these estimates, which are depicted in Table 2, provide evidence that strongly supports the theoretical prediction: higher equality favors rule of law, property rights, and political stability. This strongly confirms and complements the findings of Easterly (2001), which can be interpreted in light of the theoretical model presented before.

Inequality, Democratization and Constitutional Principles. The measures of rule of law and protection against expropriation used so far reflect the economic outcomes, property rights, directly. The model predicts a political channel through which inequality affects these outcomes, namely the type of democratization and the features of the emerging democracy. This channel may interact with complementary mechanisms linking inequality to economic outcomes and property rights protection. ${ }^{47}$ In order to investigate the empirical relevance of the political mechanism proposed in the paper directly, we collected new data on the principles stated in the democratic constitutions. The political forces that lead to the emergence of a democracy should be reflected and embodied in the democratic structures. In particular, constitutions, which are not easily and frequently changed, mirror the intentions of the constitutional assembly, that is, the different interests and the relative power of the different groups involved in the writing of the constitution. Consequently, the principles stated in the constitutions can provide valid information about the conditions under which the democratic transition occurred. The idea is thus to identify constitutional principles which are the foundation of the outcome variables of interest: quality of property rights and protection from expropriation.

will be discussed in more detail below.

${ }^{46}$ Appendix A discusses and replicates Easterly's (2001) instrumentation strategy in more detail and contains a detailed discussion of the robustness of the instrumentation and respective results. The data are those of Easterly and are available at

http://www.nyu.edu/fas/institute/dri/Easterly/Research.html.

${ }^{47}$ Inequality seems to be crucial for a number of economic outcomes other than protection of property (see e.g. Easterly, 2001). Also, it may affect these outcomes through channels different from the one studied in this paper. For example, as pointed out before, it may affect economic performance by discouraging the formation of human capital also directly and not only by leading to systems characterized by predating activities, as argued by Glaeser et al. (2004). 
To generate measures that are as objective and comparable across countries as possible, we construct three different variables by searching the content of democratic constitutions for relevant references. In particular, for all democracies contained in our data set according to the definition used before, we check the constitution for the following features: does the constitution explicitly mention the recognition and protection of private property? ${ }^{48}$ In the second measure we verify whether, in the articles mentioning property rights, private property is absolute and inviolable, or whether the state recognizes and protects private property only as long as it is instrumental for the achievement of a social purpose. ${ }^{49}$ The third measure reflects the goal of achieving a more equal distribution of natural resources: Does the constitution state the goal of implementing a land reform, reduction of large estates, or redistribution of land or natural resources in order to reduce inequality? ${ }^{50}$ These measures reflect the aims about property rights protection and redistribution in the constitution.

In light of the model, consensual democratic transitions necessarily entail a the aim of a strong protection of property rights against expropriation by the state or other members of society. ${ }^{51}$ Accordingly, the constitution should provide a strong guarantee against expropriation and redistribution of endowments. Conflictual transitions with democracy being imposed by force, on the other hand, bring about political systems in which all groups try to improve their economic position at the expense of the others. The explicit mentioning of the possibility of expropriatory interventions on grounds of achieving a social purpose or to reform the ownership of natural resources (e.g. land reforms or agrarian revolutions) can be an outflow of these forces. ${ }^{52}$ Notice that these constitutional measures are conservative indicators in the sense that,

\footnotetext{
${ }^{48}$ This was done by searching the constitutions currently in place in the countries that are coded as democracies following Persson and Tabellini (2004) for key words, see Table 11 for the data sources, the variables and details about their collection and coding. Whether property rights are constitutional was determined by key-word search for "property" and verifying whether the corresponding article mentioned that private property was recognized and protected. We collect data on 83 countries, 80 (96 percent) of which mention property rights in the constitution.

${ }^{49}$ The respective key words used were "inviolable" and "social (purpose or function)". This classification refers to the principle of property rights vis-a-vis the state, and does not refer to constitutional articles that regulate the expropriation of in the context of national emergency or public need. Such clauses, which usually contain a reference to the requirement of an appropriate compensation, are contained in virtually all constitutions. We code 29 out of 83 countries (35 percent) as tying private property to social purposes in the constitution.

${ }^{50}$ The data were collected by searching the constitutional texts for the key words "land reform", "agrarian reform" or "agrarian revolution". In our data, 21 out of 83 countries ( 25 percent) do have such a passus in their constitution.

${ }^{51}$ In fact the theory predicts that, in this case, the process of democratization is mainly aimed at signaling the intention of strongly protecting property rights in order to coordinate individual expectations.

${ }^{52}$ An illustrative example is the Constitution of Nicaragua which makes explicit references to the revolution-
} 
if property is not fully recognized in the constitution, and constitutional clauses allow for expropriation for ideological reasons, it is unlikely that property rights will be respected and enforced in reality. On the other hand, even if property rights are declared inviolable in the constitution, this does not guarantee high scores on rule of law indexes in reality.

To study the empirical relevance of the proposed political channel we proceed in two steps. We first investigate the relationship between inequality and the constitutional principles and then study the relationship between the principles and the outcomes. Table 3 uses the constitutional principles instead of the direct measures of rule of law and expropriation risk as dependent variables. Whether private property is mentioned as constitutional principle, the dependent variable used in column (1), is not related to instrumented inequality. Given that almost all democracies recognize private property, this finding is not surprising. Indicators of constitutional references to social goals to be achieved with private property, or to the aim of a land reform, the dependent variables in columns (2) and (3), respectively, appear to be strongly affected by inequality, however.

The next step of investigation is to see whether the indicators for weak constitutional foundations of property rights protection and expropriation are in fact associated with worse outcomes in terms of actually implemented property rights. To test for this link, we perform the estimation with an additional outcome equation. The predicted constitutional measures enter as explanatory variables for the measures of actual property rights enforcement used in Tables 1 and 2 before. Table 4 presents the results for both constitutional measures, the presence of a social purpose (panel A) or a reference to an equal resource distribution (panel B). ${ }^{53}$ As before, we find that larger equality significantly increases the propensity of constitutional principles that aim at strong protection of private property rights. More importantly, the prevalence of such constitutional principles significantly deteriorates the observed quality of property rights protection, and also reduces the political stability. ${ }^{54}$

ary nature of democratization (Art. 93, 97 and 107) and, accordingly, states that "the State guarantees the (co)existence of (..) private property, conditionally on it [the private property] serving the superior interests of the Nation and its social goal" (Art. 103); "The main function of the State in the economy is economic development $(. .$.$) and the realization of a more equal distribution of wealth" (Art 98); and "The agrarian reform is the$ fundamental instrument to realize a just distribution of the land (...). The State guarantees the development of the agrarian reform to fully fulfill the historic requests of the landless" (Art. 106).

${ }^{53} \mathrm{We}$ do not report results for the indicator of private property being mentioned in the constitution, which appeared not to be related to instrumented inequality for lack of variation.

${ }^{54}$ These findings remain robust even when adding Middle Class Share, our instrumented measure of equality, as additional control in the outcome equation. Only for the ICRG measure of rule of law do the constitutional variables become insignificant. 
These results provide direct support for the political channel emphasized in the theory. Inequality appears to be a crucial determinant for the type of democracy as reflected in the constitutional principles concerning property rights. These principles, in turn, influence the actual protection of property rights.

Democracy and Economic Outcomes. The theoretical model provides several further predictions, which directly relate to issues that were recently debated in the literature. In the following we attempt to evaluate their empirical relevance. One important theoretical implication that follows from Propositions 5 and 6 is that the existence of democratic regimes is not sufficient to implement efficient economic policies, in particular property rights protection. ${ }^{55}$ To test for the differential role of inequality for the political regime and economic policies, we extend the systems by one outcome equation with a democracy dummy as dependent variable. The results for democracy, depicted in the upper panel of Table 5 indicate that inequality matters for the adoption of democratic regimes, more equal countries are more likely to be democratic. The lower panel presents results for the effects of democratic regimes on the outcomes in terms of the quality of economic policies. Regardless of the outcome variable, democracy has a strong positive effect on the quality of property rights protection and the rule of law. However, one has to note that this specification forces any effect of inequality to work through democracy.

A test whether democratic regimes are sufficient to implement good economic policies, or whether, as predicted by our theory, inequality (through the process of democratization) is the true determinant of policies, is to allow for a direct effect of inequality. Results of such a specification are depicted in Table 6. The upper panel indicates that in this system inequality only has a weak effect on the propensity of a country to have democratic institutions. The corresponding institutional quality equations, depicted in the lower panel for the different measures of rule of law and political stability, are strongly affected by inequality. Whether democratic regimes are in place has no effect on economic outcomes, however. This result complements the evidence of Glaeser et al. (2004). The only significant democracy effect in Table 6 is found for political stability in column (4). ${ }^{56}$ The lower panel shows that any effect of democracy on the quality of institutions was spurious. These results suggest that democracies only play an instrumental

\footnotetext{
${ }^{55}$ For an empirical analysis of this issue we need data on democracies as well as non-democracies. We therefore use measures of the quality of actually observed property rights protection rather than measures that build on the democratic constitutions.

${ }^{56}$ While our theory primarily focuses on the role of the different types of democratic transitions for economic outcomes, it does not explicitly investigate the independent role of democratization for political stability. The results of column (4) indicate that democratic transitions have a significant direct influence on political stability, even controlling for inequality. This is in line with the findings of Przeworski (2004).
} 
role for the emergence of property rights and a rule of law.

Inequality and Fiscal Policies. Apart from the absence of property rights and property rights protection, the results of Propositions 2, 5 and 6 predict that conflictual democracies implement smaller public programs since redistribution is lower. To test for the prediction, we apply again Easterly's strategy and regress different proxies for redistribution policies on instrumented values of institutional quality on (instrumented) inequality. As measures for the extent of redistribution we use the percentage shares of GDP in terms of central government expenditure, social and welfare spending, as well as the share of enrolment in public schooling. ${ }^{57}$ The results are presented in Table 7 . Indeed, lower inequality implies larger states, hinting at the more likely implementation of consensual democracies in more equal countries. ${ }^{58}$

Notice, however, that the theory predicts the effects of inequality on government policies to work through economic institutions. Large scale redistribution emerges under consensual democracies where property rights are universally enforced. To see whether this is the case empirically, we repeat the policy outcome regressions controlling for consensual democracies by adding institutional quality variables. Results for central government expenditures and consolidated spending on social services and welfare are depicted in Table 8. In the outcome equations, we find no effect of inequality beyond the indirect effect through institutions. ${ }^{59}$ These results confirm that inequality has in fact no direct effect on government expenditures and redistribution once we control for good economic policies such as a rule of law. ${ }^{60}$ These findings also complement those by Mulligan et al. (2004) that democracies seem not to adopt systematically different fiscal policies than non-democracies. ${ }^{61}$ But they are in line with the prediction that consensual democracies redistribute more than conflictual democracies that arise in more unequal environments.

Robustness. For comparison, we also conducted the entire empirical analysis with alterna-

\footnotetext{
${ }^{57}$ The data are taken from Persson and Tabellini (2004).

${ }^{58}$ We find very similar results when using the instrumented constitutional principles for conflictual democracies from Table 3.

${ }^{59}$ This result is complementary to that of Acemoglu (2005) that strong states lead to larger government interventions than weak states.

${ }^{60}$ The results are qualitatively identical for education enrolment as policy outcome, or when using one of the other measures of institutional quality. When using the constitutional features variables together with middle class share as explanatory variables in the policy outcome equations, we find that constitutional features have an independent and significant effect, while also the middle class share exhibits a significant coefficient.

${ }^{61}$ Similarly, Perotti (1996) fails to find evidence for the prediction that higher inequality triggers larger equilibrium redistribution and size of government (the so-called "median-voter" hypothesis going back to e.g. Meltzer and Richard, 1981). Our model provides an alternative rationale for these findings.
} 
tive measures of the quality of economic structures and democratic institutions. Following Hall and Jones (1999), we used a measure that combines the variables of rule of law and expropriation risk with three other measures on bureaucratic quality, corruption and government repudiation of contracts to an index of of government anti diversion policies, GADP. This variable comprises a broad measure of property rights, see also Acemoglu, Johnson, and Robinson (2005). ${ }^{62}$ We also used other, not necessarily binary, measures of democratic institutions, such as the Freedom House measures of civil liberties and political rights that were also used by Easterly (2001) and Persson and Tabellini (2004). ${ }^{63}$ Finally, we adopted an alternative instrumentation strategy proposed by Easterly (2005) and instrumented inequality by a measure of agricultural endowments rather than tropical location. ${ }^{64}$ The use of these alternative variables and instruments delivers qualitatively identical results and confirms our earlier findings. ${ }^{65}$

\section{Conclusion}

This paper provides a theory of economic and political development that encompasses democratic transitions which are supported by a large consensus as well as democratization enforced under the shadow of conflict and against the interests of some part of the population. The results suggest that the conditions under which the transition takes place are likely to determine the economic policies and outcomes as well as the political stability of the emerging democratic systems. We find that democracies are not inherently better than non-democracies in this respect, and can generate equilibria with society-wide diversion of productive resources coupled with poor protection of property rights. This outcome is more likely if democratic transitions take place in conflictual environments. In contrast, whenever democratization is supported by all social groups including the elites, it can lead to more efficient equilibria in which the public sector ensures individuals' property rights against other individuals as well as against the state.

The model highlights the existence of multiple politico-economic equilibria that are sustained

\footnotetext{
${ }^{62}$ The variable $G A D P$ takes values between 0 and 1 and reflects an equal weighted normalized composite index of the five categories.

${ }^{63}$ For example, we used the Freedom House index of political rights and civil liberties (Gastil) that ranges from 1 to 7 with lower values indicating better democratic institutions.

${ }^{64}$ Easterly (2005) provides an in-depth discussion of the relationship of agricultural endowments, measured as the ratio between the shares of arable land suitable for wheat production and the land share suitable for sugar cane production, and inequality. He also discusses the stability of the conditions of land suitability over time, and therefore their validity as instrument for historical inequality. The data stem from the Food and Agriculture Organization, FAO, see also http://www.fao.org/ag/AGL/agll/gaez/index.htm.

${ }^{65}$ Detailed results are available upon request.
} 
by self-fulfilling expectations about poor protection of property rights. As a result, the dynamic path of an economy exhibits history dependence. Countries that initially experience conflictual democratic transitions are likely to fail to implement good economic policies even if they are eventually feasible. Democratic transitions that are initiated by an unchallenged oligarchic elite can serve as signal that allows the members of society to coordinate their expectations and therefore help establish a consensual democracy. For this to be the case, the elite must benefit from the emergence of property rights protection. On the other hand, democratic transitions that are enforced under the shadow of conflict cannot serve such a role as signal.

The taxonomy for democratic transitions suggests that the concentration of natural resources and economic inequality are the crucial determinants of democratic transitions as well as the emerging democracies. The model delivers a set of results which are discussed in line with historical and empirical evidence. Several new predictions are tested with cross-country data, using an estimation strategy that deals with endogeneity issues of the central variables. Apart from available data, we also generate new variables that reflect the conditions under which democratic transitions occurred in terms of the principles concerning property rights protection and redistribution stated in democratic constitutions. These data allow us to conduct a test of the political channel predicted by the theoretical model. The empirical findings are consistent with the theoretical results. The predictions have far reaching implications for development policy and the role of democracy for the implementation of the rule of law by linking the conditions under which democratization takes place to the likelihood of establishing stable political systems and efficient economic policies. 


\section{References}

Acemoglu, D. (2005): "Politics and Economics in Weak and Strong States," Journal of Monetary Economics, 52(7), 1199-1226.

(2006): “Modeling Inefficient Institutions," NBER Working Paper, 11940.

Acemoglu, D., And S. Johnson (2005): "Unbundling Institutions," Journal of Political Economy, 113(5), 949-995.

Acemoglu, D., S. Johnson, and J. Robinson (2001): "The Colonial Origins of Comparative Development: An Empirical Investigation," American Economic Review, 91(5), 1369-1401.

(2005): "Institutions as the Fundamental Cause of Long-Run Growth," in Handbook of Economic Growth, ed. by P. Aghion, and S. Durlauf, chap. 6. Elsevier, Amsterdam.

Acemoglu, D., S. Johnson, J. Robinson, and P. Yared (2005): "Income and Democracy," NBER Working Paper, 11205.

Acemoglu, D., and J. Robinson (2000): "Why Did the West Extend the Franchise? Democracy, Inequality, and Growth in Historical Perspective," Quarterly Journal of Economics, (4), 1167-99.

- (2001): “A Theory of Political Transitions," American Economic Review, 91(4), 938-63.

(2005): Economic Origins of Dictatorship and Democracy. Cambridge University Press, Cambridge.

Andvig, J. C., And K. O. Moene (1990): "How Corruption May Corrupt," Journal of Economic Behavior and Organization, 13(1), 63-76.

Barro, R. J. (1999): "Determinants of Democracy," Journal of Political Economy, 107(6), S158-S183.

- (2000): "Rule of Law, Democracy, and Economic Performance," in 2000 Index of Economic Freedom, ed. by M. Miles, and et al. The Heritage Foundation, Washington.

Bertocchi, G., and M. Spagat (2001): "The Politics of Cooptation," Journal of Comparative Economics, 29, 591-607.

Borx, C. (2003): Democracy and Redistribution. Cambridge University Press, Cambridge. 
Boix, C., And S. C. Stokes (2003): "Endogenous Democratization,” World Politics.

Bourguignon, F., And T. Verdier (2000): "Oligarchy, Democracy, Inequality and Growth," Journal of Development Economics, 62(2), 285-313.

Conley, J. P., And A. Temimi (2001): "Endogenous Enfranchisement when Groups' Preferences Conflict," Journal of Political Economy, 109(1), 79-102.

Easterly, W. (2001): "The Middle Class Consensus and Economic Development," Journal of Economic Growth, 6(4), 317-335.

(2005): "Inequality Does Cause Underdevelopment," CGD Working Paper, 1.

Easterly, W., And R. Levine (2003): "Tropics, Germs, and Crops: The Role of Endowments in Economic Development," Journal of Monetary Economics, 50(1), 3-39.

Engerman, S. L., And K. L. Sokoloff (1997): "Factor Endowments, Institutions and Differential Paths of Growth Among New World Economies: A View from Economic Historians from the United States," in How Latin America Fell Behind, ed. by S. Haber. Stanford University Press, Stanford CA.

(2001): "The Evolution of Suffrage Institutions in the New World," NBER Working Paper, 8512.

Glaeser, E., R. LaPorta, F. Lopez-De-Silanes, and A. Shleifer (2004): "Do Institutions Cause Growth," Journal of Economic Growth, 9, 271-303.

Glaeser, E. L., G. Ponzetto, and A. Shleifer (2006): "Why Does Democracy Need Education?," NBER Working Paper, 12128.

Gradstein, M. (2006): "Inequality, Democracy, and the Protection of Property Rights," Economic Journal, forthcoming.

Grossman, H. I. (2001): "The Creation of Effective Property Rights," American Economic Review, 91(2), 347-352.

Grossman, H. I., And M. Kim (1995): "Swords or Plowshares? A Theory of teh Security of Claims to Property," Journal of Political Economy, 103(6), 1275-1288.

(1996): "Predation and Accumulation," Journal of Economic Growth, 1(3), 333-350. 
Hall, R. E., And C. I. Jones (1999): "Why Do Some Countries Produce So Much More Output Per Worker Than Others?," Quarterly Journal of Economics, CXIV(1), 83-116.

Huber, E., D. Rueschemeyer, and J. Stephens (1993): "The Impact of Economic Development on Democracy," Journal of Economic Perspectives, 7, 71-85.

Justman, M., and M. Gradstein (1999): "The Industrial Revolution, Political Transition, and the Subsequent Decline in Inequality in 19th-Century Britain," Explorations in Economic History, 36, 109-127.

Kaufmann, D., A. KraAy, and M. Mastruzzi (2004): “Governance Matters III: Governance Indicators for 1996-2002," World Bank Research Paper, April 5, 2004.

Kaufmann, D., A. Kraay, and P. Zoido-Lobaton (1999b): "Governance Matters: Governance Indicators for 1996-2002," World Bank Research Paper, 2196.

(1999a): “Governance Matters III: Governance Indicators for 1996-2002," World Bank Research Paper, 2195.

Knack, S., And P. Keefer (1997): "Does Social Capital Have an Economic Payoff? A CrossCountry Investigation," Quarterly Journal of Economics, 112(4), 1251-1281.

KohlBerg, E. (1989): "Refinement of Nash Equilibrium: The Main Ideas," Harvard Business School Working Paper, 073.

Kohlberg, E., And J.-F. Mertens (1986): "On the Strategic Stability of Equilibria," Econometrica, 54(5), 1003-1037.

Lindert, P. H. (2000): "Three Centuries of Inequality in Britain and America," in The Handbook of Income Distribution, ed. by A. Atkinson, and F. Bourguignon, vol. 1. Elsevier, Amsterdam.

Lindert, P. H., and J. G. Williamson (2003): "Does Globalization Make the World More Unequal?," in Globalization in Historical Perspective, ed. by M. D. Bordo, A. M. Taylor, and J. G. Williamson. University of Chicago Press, Chicago.

LiPSET, S. M. (1959): "Some social requisites of democracy: economic development and political legitimacy," American Political Science Review, 53(3), 69-105.

(1960): Political Man: the Social Bases of Politics. Doubleday, Garden City, New York. 
Lizzeri, A., And N. Persico (2004): "Why did the Elites Extend the Suffrage? Democracy and the Scope of Government, with an Application to Britain's 'Age of Reform'," Quarterly Journal of Economics, 119(2), 707-765.

Llavador, H., And R. Oxoby (2005): "Partisan Competition, Growth and the Franchise," Quarterly Journal of Economics, 120(3), 1155-1189.

LuCAS, R. E. (1988): "On the Mechanism of Economic Development," Journal of Monetary Economics, 22, 3-42.

Meltzer, A. H., And S. F. Richard (1981): "A Rational Theory of the Size of Government," Journal of Political Economy, 89(5), 914-927.

Mulligan, C. B., R. Gil, and X. Sala-i Martin (2004): "Do Democracies Have Different Public Policies Than Nondemocracies?," Journal of Economic Perspectives, 18(1), 51-74.

Nelson, R., And E. Phelps (1966): "Investment in Humans, Technological Diffusion, and Economic Growth," American Economic Review (Papers and Proceedings), 56(2), 69-75.

Papaioannou, E., and G. Siouraounis (2004): "Democratization and Growth," mimeo, London Business School.

Perotti, R. (1996): "Growth, Income Distribution, and Democracy: What the Data Say," Journal of Economic Growth, 1(2), 149-187.

Persson, T., and G. Tabellini (2004): "Constitutional Rules and Fiscal Policy Outcomes," American Economic Review, 94(1), 25-45.

Przeworski, A. (2004): "Economic Development and Transitions to Democracy," mimeo, $N Y U$.

Przeworski, A., M. Alvarez, J. A. Cheibub, and F. Limongi (2000): Democracy and Development: Political Institutions and Well-Being in the World, 1950-1990. Cambridge University Press, New York.

Przeworski, A., And F. Limongi (1997): "Modernization: Theories and Facts," World Politics, 49, 155-183.

Rigobon, R., and D. Rodrik (2004): "Rule of Law, Democracy, Openness and Income: Estimating the Interrelationships," NBER Working Paper, 10750. 
Rodrik, D., A. Subramanian, and F. Trebbi (2004): "Institutions Rule: The Primacy of Institutions over Geography and Integration in Economic Development," Journal of Economic Growth, 9, 131-165.

Rodrik, D., and R. Wacziarg (2005): "Do Democratic Transitions Produce Bad Economic Outcomes?," American Economic Review, 95(3), 50-55.

Romer, P. M. (1990): "Endogenous Technological Change," Journal of Political Economy, 98(5), S71-S102.

Tavares, J., And R. Wacziarg (2001): "How Democracy Affects Growth," European Economic Review, 45(8), 1341-1378. 


\section{A Empirical Appendix}

\section{A.1 Instrumenting Inequality following Easterly (2001)}

In order to test the empirical implications of the model, we adopt Easterly's (2001) strategy of instrumentation. In particular, (in-)equality in endowments at the point of transition $(\gamma)$, which is measured by the middle class income share, is instrumented using variation in exogenous characteristics. Measuring inequality in resource endowments at the transition by current income inequality has a justification in the model. Resource endowment is the only source of inequality, and translates directly into income inequality. Moreover, the model generates an inherent perpetuation mechanism of inequality through democratic transitions in the sense that only countries with low inequality can generate consensual democratic transitions, which in turn lead to redistribution. Unequal countries, on the other hand, can only adopt conflictual democracies in which little income can be redistributed. Building on the argument by Engerman and Sokoloff $(1997,2001)$, we instrument the income share appropriated by the middle class as measure of equality by a dummy indicating commodity exporting, which itself is instrumented by tropical location. The results of replicating this first stage of Easterly's analysis, depicted in Table 9, show that commodity exporting is strongly related to tropical location. In turn, commodity exporting has a sizable negative effect on equality. ${ }^{66}$

A requirement for the instrumentation strategy to be valid is that commodity exporting or tropical location must only have an instrumental effect on the outcome variables, be it democratic structures or economic policies and the absence of predation. Any direct effect, which would imply a correlation of the instrument with the error in the outcome equation, would render the instrumentation invalid. To see whether the results are driven by a direct effect of commodity exporting or tropical location, we add the commodity dummy or the tropical location dummy directly in the last stage regression. The results, depicted in Table 10, show that in both cases there is no evidence for direct effects, so the instruments appear to be valid. The effects for instrumented inequality in terms of middle class income shares are qualitatively unchanged, but become weaker when tropical location is added as a control, which is in line with Easterly's (2001) findings. While the fact that neither commodity nor tropics dummy have a significant coefficient and thus seem uncorrelated with the error in the outcome equation is no proof for the validity of the instrument, we take it as support for the instrumentation strategy.

\footnotetext{
${ }^{66}$ See Easterly (2001) for an extensive discussion of the instrumentation strategy and robustness checks.
} 


\section{B Tables}

Table 1: Determinants of Property Rights Protection

\begin{tabular}{|c|c|c|c|c|}
\hline Dependent Variable & $\begin{array}{l}\text { Rule of Law } \\
\text { (Kaufmann) } \\
\text { (1) }\end{array}$ & $\begin{array}{l}\text { Rule of Law } \\
\text { (ICRG) } \\
(2)\end{array}$ & $\begin{array}{c}\text { Protection against } \\
\text { Expropriation (ICRG) } \\
(3)\end{array}$ & $\begin{array}{c}\text { Political Stability } \\
\text { (Kaufmann) } \\
(4)\end{array}$ \\
\hline \multirow[t]{2}{*}{ Middle Class Share } & $0.067 * * *$ & $0.106^{* * *}$ & $0.128^{* * *}$ & $0.059^{* * *}$ \\
\hline & {$[0.013]$} & {$[0.019]$} & {$[0.032]$} & {$[0.017]$} \\
\hline \multirow[t]{2}{*}{ Tropics Dummy } & $-0.440^{*}$ & -0.199 & $-0.910^{* *}$ & -0.215 \\
\hline & {$[0.228]$} & {$[0.369]$} & {$[0.407]$} & {$[0.272]$} \\
\hline \multirow[t]{2}{*}{ Commodity Exporting } & $-0.502^{* *}$ & -0.513 & -0.596 & 0.023 \\
\hline & {$[0.220]$} & {$[0.328]$} & {$[0.448]$} & {$[0.265]$} \\
\hline \multirow[t]{2}{*}{ Oil Dummy } & $-0.737 * *$ & -0.35 & -0.924 & $-1.076^{*}$ \\
\hline & {$[0.323]$} & {$[0.462]$} & {$[0.781]$} & {$[0.586]$} \\
\hline \multirow[t]{2}{*}{ Ethnic Fragmentation } & $-0.005^{*}$ & -0.007 & -0.004 & $-0.008^{* *}$ \\
\hline & {$[0.003]$} & {$[0.005]$} & {$[0.005]$} & {$[0.003]$} \\
\hline \multirow[t]{2}{*}{ Constant } & $-2.082^{* * *}$ & -0.593 & 2.328 & $-2.187^{* *}$ \\
\hline & {$[0.657]$} & {$[0.971]$} & {$[1.705]$} & {$[0.885]$} \\
\hline Observations & 83 & 75 & 75 & 82 \\
\hline R-squared & 0.61 & 0.5 & 0.59 & 0.38 \\
\hline
\end{tabular}

Notes: Results from OLS estimations. Exogenous variables are income share of middle class, tropical location, commodity producing dummy, oil exporting dummy and ethnic fragmentation, all taken from Easterly (2001). Measures Rule of Law (1) are point estimates of Kaufman et al.'s (2004) fifth cluster of governance, supplied by the World Bank. Measures of Rule of Law (2) and Protection against Risk of Expropriation (3) are taken from International Country Risk Guide; (4) are point estimates of Kaufman et al.'s (2004) second cluster of governance, supplied by the World Bank. Higher scores imply better outcomes. Robust standard errors are in parentheses. Significance at 10, 5 percent and 1 percent level is indicated by ${ }^{*},{ }^{* *}$ and ${ }^{* * *}$, respectively. 
Table 2: Middle Class Share as Predictor of Property Rights Protection

\begin{tabular}{rcccc}
\hline \hline Dependent Variable & $\begin{array}{c}\text { Rule of Law } \\
\text { Kaufmann }\end{array}$ & $\begin{array}{c}\text { Rule of Law } \\
(\mathrm{ICRG}) \\
(1)\end{array}$ & $\begin{array}{c}\text { Protection against } \\
\text { Expropriation (ICRG) }\end{array}$ & $\begin{array}{c}\text { Political Stability } \\
(\text { Kaufmann) } \\
(4)\end{array}$ \\
\hline Middle Class Share & $0.162^{* * *}$ & $0.178^{* * *}$ & $0.243^{* * *}$ & $0.092^{* * *}$ \\
& {$[0.027]$} & {$[0.033]$} & {$[0.037]$} & {$[0.029]$} \\
Ethnic Fragmentation & -0.004 & -0.007 & -0.003 & $-0.007^{*}$ \\
& {$[0.003]$} & {$[0.005]$} & {$[0.005]$} & {$[0.004]$} \\
Constant & $-6.887^{* * *}$ & $-4.229^{* * *}$ & $-3.561^{* *}$ & $-3.824^{* * *}$ \\
& {$[1.269]$} & {$[1.629]$} & {$[1.765]$} & {$[1.431]$} \\
\hline Observations & 83 & 75 & 75 & 82 \\
\hline
\end{tabular}

Notes: Results from 3SLS estimations. Exogenous variables are tropical location, oil exporting dummy and ethnic fragmentation. Endogenous variables are commodity producing dummy, income share of middle class, and different measures of the quality of institutions, where higher scores imply better institutions. Measures Rule of Law (1) are point estimates of Kaufman et al.'s (2004) fifth cluster of governance, supplied by the World Bank. Measures of Rule of Law (2) and Protection against Risk of Expropriation (3) are taken from International Country Risk Guide; (4) are point estimates of Kaufman et al.'s (2004) second cluster of governance, supplied by the World Bank. Higher scores imply better outcomes. In each column, middle class income share is instrumented as in Table 9. Standard errors are in parentheses. Significance at 10, 5 percent and 1 percent level is indicated by ${ }^{*},{ }^{* *}$ and ${ }^{* * *}$, respectively.

Table 3: Middle Class Share as Predictor of Constitutional Principles

\begin{tabular}{|c|c|c|c|}
\hline Dependent Variable & $\begin{array}{l}\text { Private Property } \\
\text { Constitutional } \\
\text { (1) }\end{array}$ & $\begin{array}{l}\text { Social Purpose of } \\
\text { Private Property } \\
\text { (2) }\end{array}$ & $\begin{array}{c}\text { Equal Resource Distribution } \\
\text { as Constitutional Goal } \\
(3)\end{array}$ \\
\hline \multirow[t]{2}{*}{ Middle Class Share } & -0.009 & $-0.035^{* * *}$ & $-0.036^{* * *}$ \\
\hline & {$[0.005]$} & {$[0.012]$} & {$[0.012]$} \\
\hline \multirow[t]{2}{*}{ Ethnic Fragmentation } & -0.001 & $-0.005^{* * *}$ & $-0.003^{*}$ \\
\hline & {$[0.001]$} & {$[0.002]$} & {$[0.002]$} \\
\hline \multirow[t]{2}{*}{ Constant } & $1.397^{* * *}$ & $2.208^{* * *}$ & $2.085^{* * *}$ \\
\hline & {$[0.261]$} & {$[0.605]$} & {$[0.600]$} \\
\hline Observations & 57 & 57 & 57 \\
\hline
\end{tabular}

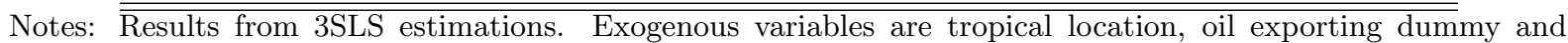
ethnic fragmentation. Endogenous variables are (1) a dummy indicating whether private property is mentioned in the constitution, (2) a dummy indicating whether private property recognition in the constitution is subject to achieving a social goal, and (3) a dummy indicating whether the constitution mentions the goal of land reform and an equal distribution of natural resources, see text and Table 11 for details. In each column, middle class income share is instrumented as in Table 9. Standard errors are in parentheses. Significance at 10, 5 percent and 1 percent level is indicated by ${ }^{*},{ }^{* *}$ and ${ }^{* * *}$, respectively. 
Table 4: Middle Class Share, Constitutional Principles and Property Rights

\section{Panel A: Social Purpose}

\begin{tabular}{rcccc}
\hline Dependent Variable & \multicolumn{4}{c}{ Social Purpose of Private Property } \\
& $(1)$ & $(2)$ & $(3)$ & $(4)$ \\
\hline Middle Class Share & $-0.029^{* *}$ & $-0.037^{* * *}$ & $-0.034^{* * *}$ & $-0.037^{* * *}$ \\
& {$[0.011]$} & {$[0.011]$} & {$[0.011]$} & {$[0.012]$} \\
Ethnic Fragmentation & $-0.005^{* *}$ & $-0.005^{* *}$ & $-0.005^{* *}$ & $-0.006^{* * *}$ \\
& {$[0.002]$} & {$[0.002]$} & {$[0.002]$} & {$[0.002]$} \\
Constant & $1.883^{* * *}$ & $2.300^{* * *}$ & $2.147^{* * *}$ & $2.298^{* * *}$ \\
& {$[0.570]$} & {$[0.568]$} & {$[0.559]$} & {$[0.598]$} \\
\hline Dependent Variable & Rule of Law & Rule of Law & Protection against & Political Stability \\
& Kaufmann) & $($ ICRG) & Expropriation (ICRG) & $($ Kaufmann $)$ \\
& $(1)$ & $(2)$ & $(3)$ & $(4)$ \\
\hline Ethnic Fragmentation & $-0.026^{* * *}$ & $-0.037^{* * *}$ & $-0.042^{* * *}$ & $-0.019^{* * *}$ \\
& {$[0.008]$} & {$[0.012]$} & {$[0.014]$} & {$[0.005]$} \\
Social Purpose of & $-4.668^{* * *}$ & $-5.121^{* * *}$ & $-6.885^{* * *}$ & $-1.991^{* * *}$ \\
Private Property & {$[1.282]$} & {$[1.723]$} & {$[2.020]$} & {$[0.700]$} \\
Constant & $3.294^{* * *}$ & $7.144^{* * *}$ & $12.007^{* * *}$ & $1.738^{* * *}$ \\
& {$[0.699]$} & {$[0.967]$} & {$[1.141]$} & $50.392]$ \\
\hline Observations & 57 & 54 & 54 & 56 \\
\hline \hline
\end{tabular}

Panel B: Equal Resource Distribution

\begin{tabular}{|c|c|c|c|c|}
\hline \multirow[t]{2}{*}{ Dependent Variable } & \multicolumn{4}{|c|}{ Equal Resource Distribution as Constitutional Goal } \\
\hline & $(1)$ & $(2)$ & $(3)$ & $(4)$ \\
\hline \multirow[t]{2}{*}{ Middle Class Share } & $-0.049 * * *$ & $-0.038^{* * *}$ & $-0.044^{* * *}$ & $-0.040 * * *$ \\
\hline & {$[0.011]$} & {$[0.010]$} & {$[0.010]$} & {$[0.012]$} \\
\hline \multirow[t]{2}{*}{ Ethnic Fragmentation } & $-0.004^{* *}$ & -0.003 & $-0.004^{*}$ & $-0.004^{*}$ \\
\hline & {$[0.002]$} & {$[0.002]$} & {$[0.002]$} & {$[0.002]$} \\
\hline \multirow[t]{2}{*}{ Constant } & $2.725^{* * *}$ & $2.194^{* * *}$ & $2.526^{* * *}$ & $2.334^{* * *}$ \\
\hline & {$[0.523]$} & {$[0.514]$} & {$[0.491]$} & {$[0.586]$} \\
\hline \multirow[t]{3}{*}{ Dependent Variable } & Rule of Law & Rule of Law & Protection against & Political Stability \\
\hline & (Kaufmann) & (ICRG) & Expropriation (ICRG) & (Kaufmann) \\
\hline & (1) & (2) & $(3)$ & (4) \\
\hline \multirow[t]{2}{*}{ Ethnic Fragmentation } & $-0.015^{* *}$ & $-0.027 * *$ & $-0.027^{* *}$ & $-0.015^{* * *}$ \\
\hline & {$[0.006]$} & {$[0.010]$} & {$[0.011]$} & {$[0.004]$} \\
\hline \multirow{4}{*}{$\begin{array}{r}\text { Equal Resource Distribution } \\
\text { as Constitutional Goal } \\
\text { Constant }\end{array}$} & $-2.487 * * *$ & $-4.994 * * *$ & $-4.996 * * *$ & $-1.661 * * *$ \\
\hline & {$[0.876]$} & [1.395] & [1.438] & {$[0.620]$} \\
\hline & $1.898 * * *$ & $6.374^{* * *}$ & $10.378^{* * *}$ & $1.337 * * *$ \\
\hline & {$[0.405]$} & {$[0.673]$} & {$[0.710]$} & {$[0.287]$} \\
\hline Observations & 57 & 54 & 54 & 56 \\
\hline
\end{tabular}

Notes: Results from 3SLS estimations, each column in a panel comprises two separate outcome equations within one system. Panel A and B reflect different estimations of different systems. In each estimation, exogenous variables are tropical location, oil exporting dummy and ethnic fragmentation. The endogenous outcome variable in the upper equation of Panel A is dummy indicating whether private property recognition in the constitution is subject to achieving a social goal, see text and Table 11 for details. The endogenous outcome variable in the upper equation of Panel B is a dummy indicating whether the constitution mentions the goal of land reform and an equal distribution of natural resources, see text and Table 11 for details. The endogenous variables in the lower equations of both panels are different measures of the quality of institutions (lower panel), where higher scores imply better institutions. Democracy dummy is taken from Persson and Tabellini (2004), see footnote 39. Measures Rule of Law (1) are point estimates of Kaufman et al.'s (2004) fifth cluster of governance, supplied by the World Bank. Measures of Rule of Law (2) and Protection against Risk of Expropriation (3) are taken from International Country Risk Guide; (4) are point estimates of Kaufman et al.'s (2004) second cluster of governance, supplied by the World Bank. Higher scores imply better outcomes. In each column, middle class income share is instrumented as in Table 9. Standard errors are in parentheses. Significance at 10, 5 percent and 1 percent level is indicated by ${ }^{*},{ }^{* *}$ and ${ }^{* * *}$, respectively. 
Table 5: Middle Class Share, Democracy, and Property Rights Protection

\begin{tabular}{rcccc}
\hline \hline Dependent Variable & $\begin{array}{c}\text { Democracy } \\
(1)\end{array}$ & $\begin{array}{c}\text { Democracy } \\
(2)\end{array}$ & $\begin{array}{c}\text { Democracy } \\
(3)\end{array}$ & $\begin{array}{c}\text { Democracy } \\
(4)\end{array}$ \\
\hline Middle Class Share & $0.037^{* * *}$ & $0.035^{* * *}$ & $0.038^{* * *}$ & 0.016 \\
& {$[0.009]$} & {$[0.009]$} & {$[0.008]$} & {$[0.012]$} \\
Ethnic Fragmentation & -0.001 & -0.001 & -0.001 & -0.002 \\
& {$[0.002]$} & {$[0.002]$} & {$[0.002]$} & {$[0.002]$} \\
Constant & $-0.946^{* *}$ & $-0.808^{*}$ & $-0.957^{* *}$ & 0.047 \\
& {$[0.432]$} & {$[0.441]$} & {$[0.399]$} & {$[0.561]$} \\
\hline Dependent Variable & Rule of Law & Rule of Law & Protection against & Political Stability \\
& (Kaufmann) & $($ ICRG) & Expropriation (ICRG) & $($ Kaufmann) \\
& $(1)$ & $(2)$ & $(3)$ & $(4)$ \\
\hline Ethnic Fragmentation & -0.001 & -0.004 & 0.001 & 0.001 \\
& {$[0.007]$} & {$[0.008]$} & {$[0.010]$} & {$[0.007]$} \\
Democracy & $4.607^{* * *}$ & $4.680^{* * *}$ & $6.385^{* * *}$ & {$\left[1.964^{* * *}\right.$} \\
& {$[0.989]$} & {$[1.305]$} & {$[1.441]$} & $-3.475^{* * *}$ \\
Constant & $-2.878^{* * *}$ & 0.28 & $2.640^{* *}$ & {$[0.963]$} \\
\hline Observations & {$[0.881]$} & {$[1.200]$} & {$[1.337]$} & 82 \\
\hline \hline
\end{tabular}

Notes: Results from 3SLS estimations, each column comprises two separate outcome equations within one system. Exogenous variables are tropical location, oil exporting dummy and ethnic fragmentation. Endogenous variables are a democracy dummy (upper panel) and and different measures of the quality of institutions (lower panel), where higher scores imply better institutions. Democracy dummy is taken from Persson and Tabellini (2004), see footnote 39. Measures Rule of Law (1) are point estimates of Kaufman et al.'s (2004) fifth cluster of governance, supplied by the World Bank. Measures of Rule of Law (2) and Protection against Risk of Expropriation (3) are taken from International Country Risk Guide; (4) are point estimates of Kaufman et al.'s (2004) second cluster of governance, supplied by the World Bank. Higher scores imply better outcomes. In each column, middle class income share is instrumented as in Table 9. Standard errors are in parentheses. Significance at 10, 5 percent and 1 percent level is indicated by ${ }^{*},{ }^{* *}$ and ${ }^{* * *}$, respectively. 
Table 6: The Instrumental Role of Democracy for Property Rights Protection

\begin{tabular}{ccccc}
\hline \hline Dependent Variable & $\begin{array}{c}\text { Democracy } \\
(1)\end{array}$ & $\begin{array}{c}\text { Democracy } \\
(2)\end{array}$ & $\begin{array}{c}\text { Democracy } \\
(3)\end{array}$ & $\begin{array}{c}\text { Democracy } \\
(4)\end{array}$ \\
\hline Middle Class Share & $0.028^{*}$ & $0.020^{*}$ & $0.020^{*}$ & $0.029^{* *}$ \\
& {$[0.014]$} & {$[0.012]$} & {$[0.012]$} & {$[0.015]$} \\
Ethnic Fragmentation & -0.001 & -0.002 & -0.002 & -0.001 \\
& {$[0.002]$} & {$[0.002]$} & {$[0.002]$} & {$[0.002]$} \\
Constant & -0.54 & -0.096 & -0.096 & -0.59 \\
& {$[0.700]$} & {$[0.590]$} & {$[0.590]$} & {$[0.706]$} \\
\hline Dependent Variable & Rule of Law & Rule of Law & Protection against & Political Stability \\
& $($ Kaufmann) & $(\mathrm{ICRG})$ & Expropriation (ICRG) & $($ Kaufmann) \\
& $(1)$ & $(2)$ & $(3)$ & $(4)$ \\
\hline Middle Class Share & $0.146^{* * *}$ & $0.185^{* * *}$ & $0.240^{* * *}$ & -0.112 \\
& {$[0.046]$} & {$[0.043]$} & {$[0.046]$} & {$[0.071]$} \\
Ethnic Fragmentation & -0.004 & -0.008 & -0.003 & 0 \\
& {$[0.003]$} & {$[0.006]$} & {$[0.006]$} & {$[0.007]$} \\
Democracy & 0.554 & -0.379 & 0.156 & $6.859^{* * *}$ \\
& {$[1.361]$} & {$[1.447]$} & {$[1.605]$} & {$[1.494]$} \\
Constant & $-6.578^{* * *}$ & $-4.232^{* * *}$ & $-3.521^{* *}$ & 0.358 \\
& {$[1.378]$} & {$[1.629]$} & {$[1.695]$} & {$[2.838]$} \\
\hline Observations & 83 & 75 & 75 & 82 \\
\hline
\end{tabular}

Notes: Results from 3SLS estimations, each column comprises two separate outcome equations within one system. Exogenous variables are tropical location, oil exporting dummy and ethnic fragmentation. Endogenous variables are a democracy dummy (upper panel) and and different measures of the quality of institutions (lower panel), where higher scores imply better institutions. Democracy dummy is taken from Persson and Tabellini (2004), see footnote 39. Measures Rule of Law (1) are point estimates of Kaufman et al.'s (2004) fifth cluster of governance, supplied by the World Bank. Measures of Rule of Law (2) and Protection against Risk of Expropriation (3) are taken from International Country Risk Guide; (4) are point estimates of Kaufman et al.'s (2004) second cluster of governance, supplied by the World Bank. Higher scores imply better outcomes. In each column, middle class income share is instrumented as in Table 9. Standard errors are in parentheses. Significance at 10, 5 percent and 1 percent level is indicated by ${ }^{*},{ }^{* *}$ and ${ }^{* * *}$, respectively.

Table 7: Middle Class Share, Redistributive Policy and Size of State

\begin{tabular}{rccc}
\hline \hline Dependent Variable & $\begin{array}{c}\text { Central Government } \\
\text { Expenditure } \\
(1)\end{array}$ & $\begin{array}{c}\text { Social Services } \\
\text { and Welfare }\end{array}$ & $\begin{array}{c}\text { Size of Education } \\
\text { Sector } \\
(3)\end{array}$ \\
\hline Middle Class Share & $1.004^{* * *}$ & $0.851^{* * *}$ & $1.841^{* * *}$ \\
& {$[0.256]$} & {$[0.137]$} & {$[0.436]$} \\
Ethnic Fragmentation & $-0.102^{* *}$ & $-0.065^{* *}$ & $-0.160^{* *}$ \\
& {$[0.043]$} & {$[0.026]$} & {$[0.073]$} \\
Constant & -15.815 & $-30.439^{* * *}$ & 8.562 \\
& {$[12.738]$} & {$[6.891]$} & {$[21.619]$} \\
\hline Observations & 57 & 48 & 58 \\
\hline
\end{tabular}

Notes: $\overline{\text { Results from 3SLS estimations. Exogenous variables are tropical location, oil exporting }}$ dummy and ethnic fragmentation. Endogenous variables are commodity producing dummy, income share of middle class, and different measures of size of state and redistribution. (1) is central government expenditure as percentage of GDP; 2 consolidated central government expenditures on social services and welfare as percentage of GDP; (3) total enrolment in primary and secondary education as percentage of the relevant age group in the population; all taken from Persson and Tabellini (2004) (cgexp, ssw and eduger, respectively.). In each column, middle class income share is instrumented as in Table 9. Standard errors are in parentheses. Significance at 10, 5 percent and 1 percent level is indicated by ${ }^{*},{ }^{* *}$ and ${ }^{* * *}$, respectively. 
Table 8: The Indirect Role of Middle Class Share for Redistribution and the Size of State

\begin{tabular}{|c|c|c|c|c|}
\hline Dependent Variable & $\begin{array}{l}\text { Rule of Law } \\
\text { (Kaufmann) } \\
(1)\end{array}$ & $\begin{array}{c}\text { Protection against } \\
\text { Expropriation (ICRG) } \\
(2)\end{array}$ & $\begin{array}{l}\text { Rule of Law } \\
\text { (Kaufmann) } \\
(3)\end{array}$ & $\begin{array}{c}\text { Protection against } \\
\text { Expropriation (ICRG) } \\
(4)\end{array}$ \\
\hline \multirow[t]{2}{*}{ Middle Class Share } & $0.134^{* * *}$ & $0.233^{* * *}$ & $0.134^{* * *}$ & $0.234^{* * *}$ \\
\hline & {$[0.020]$} & {$[0.029]$} & {$[0.017]$} & {$[0.027]$} \\
\hline \multirow[t]{2}{*}{ Ethnic Fragmentation } & $-0.006^{*}$ & -0.008 & $-0.004^{*}$ & -0.005 \\
\hline & {$[0.003]$} & {$[0.005]$} & {$[0.002]$} & {$[0.004]$} \\
\hline \multirow[t]{2}{*}{ Constant } & $-5.428 * * *$ & $-2.733^{*}$ & $-5.384^{* * *}$ & $-2.829 * *$ \\
\hline & {$[0.968]$} & {$[1.447]$} & {$[0.859]$} & {$[1.319]$} \\
\hline Dependent Variable & $\begin{array}{l}\text { Central Government } \\
\text { Expenditure }\end{array}$ & $\begin{array}{l}\text { Central Government } \\
\text { Expenditure }\end{array}$ & $\begin{array}{l}\text { Social Services } \\
\text { and Welfare }\end{array}$ & $\begin{array}{l}\text { Social Services } \\
\text { and Welfare }\end{array}$ \\
\hline \multirow[t]{2}{*}{ Middle Class Share } & -0.809 & -1.373 & -1.418 & -1.592 \\
\hline & {$[0.851]$} & {$[1.054]$} & [1.068] & {$[1.020]$} \\
\hline Rule of Law & $13.907^{* *}$ & & $17.082^{* *}$ & \\
\hline (Kaufmann) & {$[5.642]$} & & {$[7.536]$} & \\
\hline Protection against & & $10.389^{* *}$ & & $10.674^{* *}$ \\
\hline Expropriation (ICRG) & & {$[4.205]$} & & {$[4.384]$} \\
\hline \multirow[t]{2}{*}{ Constant } & 56.395 & 10.334 & 60.737 & -3.397 \\
\hline & [36.403] & [19.035] & {$[44.515]$} & {$[14.803]$} \\
\hline Observations & 57 & 54 & 48 & 46 \\
\hline
\end{tabular}

Notes: Results from 3SLS estimations, each column comprises two separate outcome equations within one system. Exogenous variables are tropical location, oil exporting dummy and ethnic fragmentation. Endogenous variables are different measures of the quality of institutions (upper panel) where higher scores imply better institutions, and policy outcomes (lower panel). The Kaufmann measures of rule of law (1) and (3) are point estimates of Kaufman et al.'s (2004) fifth cluster of governance, supplied by the World BankMeasures of Protection against Risk of Expropriation in (2) and (4) are taken from International Country Risk Guide; Central government expenditure as percentage of GDP in (1), (2) and (3) and consolidated central government expenditures on social services and welfare as percentage of GDP in (4), (5), and (6)are taken from Persson and Tabellini (2004). In each column, middle class income share is instrumented as in Table 9. Standard errors are in parentheses. Significance at 10, 5 percent and 1 percent level is indicated by ${ }^{*},{ }^{* *}$ and ${ }^{* * *}$, respectively.

Table 9: Middle Class Share, Commodity Exporting and Tropical Location

\begin{tabular}{rcc}
\hline \hline Dependent Variable & Commodity & $\begin{array}{c}\text { Middle Class Share } \\
\text { Quintile }\end{array}$ \\
\hline Tropics Dummy & $0.383^{* * *}$ & \\
& {$[0.072]$} & \\
Oil Dummy & $-0.305^{* *}$ & $-10.876^{* * *}$ \\
& {$[0.153]$} & {$[4.035]$} \\
Commodity & & $-19.612^{* * *}$ \\
& & {$[4.811]$} \\
Constant & 0.05 & $51.627^{* * *}$ \\
& {$[0.051]$} & {$[1.461]$} \\
\hline Observations & 101 & 101 \\
\hline \hline
\end{tabular}

Notes: Results from $\overline{\overline{\text { 3SLS estimations. Exogenous variables are tropical location }}}$ and oil exporting dummy; endogenous variables are commodity producing dummy and middle class income share, see text and Easterly (2001) for a detailed description. Standard errors are in brackets. Significance at 10,5 percent and 1 percent level is indicated by ${ }^{*},{ }^{* *}$ and ${ }^{* * *}$, respectively. 
Table 10: Middle Class Share as Predictor of Property Rights: Robustness

\begin{tabular}{|c|c|c|c|c|}
\hline Dependent Variable & $\begin{array}{l}\text { Rule of Law } \\
\text { (Kaufmann) } \\
(1)\end{array}$ & $\begin{array}{l}\text { Rule of Law } \\
\text { (ICRG) } \\
(2)\end{array}$ & $\begin{array}{c}\text { Protection against } \\
\text { Expropriation (ICRG) } \\
(3)\end{array}$ & $\begin{array}{c}\text { Political Stability } \\
\text { (Kaufmann) } \\
(4)\end{array}$ \\
\hline \multirow[t]{2}{*}{ Commodity Dummy } & 0.407 & 0.014 & 0.448 & $1.874^{*}$ \\
\hline & {$[0.839]$} & {$[1.135]$} & {$[1.380]$} & {$[1.071]$} \\
\hline \multirow[t]{2}{*}{ Middle Class Share } & $0.177^{* * *}$ & $0.178 * * *$ & $0.258 * * *$ & $0.156^{* * *}$ \\
\hline & {$[0.041]$} & {$[0.044]$} & {$[0.052]$} & {$[0.053]$} \\
\hline \multirow[t]{2}{*}{ Ethnic Fragmentation } & -0.004 & -0.007 & -0.003 & $-0.007^{*}$ \\
\hline & {$[0.003]$} & {$[0.006]$} & {$[0.006]$} & {$[0.004]$} \\
\hline \multirow[t]{2}{*}{ Constant } & $-7.647 * * *$ & $-4.252^{*}$ & $-4.336^{*}$ & $-7.231 * * *$ \\
\hline & [1.997] & {$[2.177]$} & {$[2.573]$} & {$[2.630]$} \\
\hline \multirow[t]{2}{*}{ Tropics Dummy } & 0.341 & 0.014 & 0.427 & 1.626 \\
\hline & {$[0.742]$} & {$[1.069]$} & [1.359] & {$[1.151]$} \\
\hline \multirow[t]{2}{*}{ Middle Class Share } & $0.206^{*}$ & 0.179 & $0.292^{*}$ & $0.292^{*}$ \\
\hline & {$[0.106]$} & {$[0.126]$} & {$[0.162]$} & {$[0.163]$} \\
\hline \multirow[t]{2}{*}{ Ethnic Fragmentation } & -0.004 & -0.007 & -0.002 & -0.006 \\
\hline & {$[0.004]$} & {$[0.005]$} & {$[0.006]$} & {$[0.006]$} \\
\hline \multirow[t]{2}{*}{ Constant } & $-9.081^{*}$ & -4.308 & -6.023 & $-13.882^{*}$ \\
\hline & {$[5.321]$} & {$[6.405]$} & {$[8.186]$} & [8.192] \\
\hline Observations & 83 & 75 & 75 & 82 \\
\hline
\end{tabular}

Notes: Results from 3SLS estimations. Exogenous variables are tropical location, oil exporting dummy and ethnic fragmentation. Endogenous variables are commodity producing dummy, income share of middle class, and different measures of the quality of institutions, where higher scores imply better institutions. The Kaufmann measures of rule of law (1) are point estimates of Kaufman et al.'s (2004) fifth cluster of governance, supplied by the World Bank. Measures Rule of Law (2) and Protection against Risk of Expropriation (3) are taken from International Country Risk Guide; variables of political stability in (4) are point estimates of Kaufman et al.'s (2004) second cluster of governance, supplied by the World Bank. In each column, middle class income share is instrumented as in Table 9. Standard errors are in parentheses. Significance at 10, 5 percent and 1 percent level is indicated by ${ }^{*},{ }^{* *}$ and ${ }^{* * *}$, respectively. 
Table 11: Constitutional Principles

\begin{tabular}{|c|c|c|c|c|c|c|}
\hline \multirow[t]{2}{*}{ Country } & \multicolumn{2}{|c|}{$\begin{array}{l}\text { Private Property } \\
\text { Constitutional }\end{array}$} & $\begin{array}{l}\text { Social } \\
\text { Privat }\end{array}$ & $\begin{array}{l}\text { ose of } \\
\text { perty }\end{array}$ & $\begin{array}{l}\text { Equal } \\
\text { as Con }\end{array}$ & $\begin{array}{l}\text { urce Distribution } \\
\text { tional Goal }\end{array}$ \\
\hline & (1) & based on article & $(2)$ & based on article & $(3)$ & based on article \\
\hline ARGENTINA & 1 & 14 & 0 & & 0 & \\
\hline AUSTRALIA & & & & & & \\
\hline AUSTRIA & 0 & & 0 & & 1 & 12 \\
\hline BAHAMAS & 1 & 15 & 0 & & 0 & \\
\hline BANGLADESH & 1 & 42 & 1 & 42 & 1 & 16 \\
\hline BARBADOS & 1 & 16 & 0 & & 0 & \\
\hline BELARUS & 1 & 29,44 & 0 & & 0 & \\
\hline BELGIUM & 1 & 16 & 0 & & 0 & \\
\hline BELIZE & 1 & 3 & 1 & 9 & 0 & \\
\hline BOLIVIA & 1 & 7,22 & 1 & 7,22 & 1 & 175 \\
\hline BOTSWANA & 1 & 8,9 & 0 & & 0 & \\
\hline BRAZIL & 1 & 5 & 1 & 5 & 1 & 184 \\
\hline BULGARIA & 1 & 6 & 0 & & 0 & \\
\hline CANADA & 0 & & 0 & & 0 & \\
\hline CHILE & 1 & 23 & 1 & 24 & 0 & \\
\hline COLOMBIA & 1 & 58 & 1 & 58 & 1 & 64 \\
\hline COSTA RICA & 1 & 23 & 1 & 45 & 0 & \\
\hline CYPRUS & 1 & 12,231 & 0 & & 1 & 23 \\
\hline CZECH REPUBLIC & 0 & & 0 & & 0 & \\
\hline DENMARK & 1 & 73 & 0 & & 0 & \\
\hline DOMINICAN REPUBLIC & 1 & 13 & 1 & 13 & 1 & 13 \\
\hline ECUADOR & 1 & 30 & 1 & 30 & 1 & 267 \\
\hline EL SALVADOR & 1 & 2 & 1 & 103 & 1 & 104,105 \\
\hline ESTONIA & 1 & 32 & 0 & & 0 & \\
\hline FIJI & 1 & 26 & 0 & & 0 & \\
\hline FINLAND & 1 & 15 & 0 & & 0 & \\
\hline FRANCE & 1 & 34 & 0 & & 0 & \\
\hline GAMBIA & 1 & 22 & 1 & 22 & 0 & \\
\hline GERMANY & 1 & 14 & 0 & & 0 & \\
\hline GHANA & 1 & 13 & 0 & & 0 & \\
\hline GREECE & 1 & 17 & 0 & & 0 & \\
\hline GUATEMALA & 1 & 39 & 0 & & 0 & \\
\hline HONDURAS & 1 & 61,103 & 1 & 103 & 1 & $245(32)$ \\
\hline HUNGARY & 1 & 9,13 & 0 & & 0 & \\
\hline ICELAND & 1 & 72 & 0 & & 0 & \\
\hline INDIA & 1 & 26 & 0 & & 0 & \\
\hline IRELAND & 1 & 40,43 & 1 & 43 & 0 & \\
\hline ISRAEL & 1 & BL s. 3 & 0 & & 0 & \\
\hline ITALY & 1 & 42 & 1 & 42 & 1 & 44 \\
\hline JAMAICA & 1 & 13,18 & 0 & & 0 & \\
\hline JAPAN & 1 & 29 & 0 & & 0 & \\
\hline KOREA, SOUTH & 1 & 13,23 & 1 & 13,23 & 0 & 121 \\
\hline LATVIA & 1 & 105 & 0 & & 0 & \\
\hline LUXEMBOURG & 1 & 16 & 0 & & 0 & \\
\hline MALAWI & 1 & 28 & 0 & & 0 & \\
\hline MALAYSIA & 1 & 12 & 0 & & 0 & \\
\hline MALTA & 1 & 32 & 1 & 37 & 0 & \\
\hline MAURITIUS & 1 & 3 & 0 & & 0 & \\
\hline MEXICO & 1 & 14 & 1 & & 1 & 11 \\
\hline NAMIBIA & 1 & 16 & 0 & & 0 & \\
\hline NEPAL & 1 & 17 & 0 & & 0 & \\
\hline NETHERLANDS & 1 & 14 & 0 & & 0 & \\
\hline NEW ZEALAND & 1 & 21 & 0 & & 0 & \\
\hline NICARAGUA & 1 & 5 & 1 & 5,103 & 1 & 106,107 \\
\hline NORWAY & 1 & 105 & 0 & & 0 & \\
\hline PAKISTAN & 1 & 23 & 0 & & 0 & \\
\hline PAPUA NEW GUINEA & 1 & & 1 & 53 & 0 & \\
\hline PARAGUAY & 1 & 43 & 1 & 43 & 1 & $109,115,116$ \\
\hline PERU & 1 & 8,16 & 0 & & 0 & \\
\hline PHILIPPINES & 1 & 3 & 0 & & 0 & \\
\hline POLAND & 1 & 46,64 & 0 & & 0 & \\
\hline PORTUGAL & 1 & 62 & 0 & & 1 & 93 \\
\hline ROMANIA & 1 & 4,41 & 0 & & 0 & \\
\hline RUSSIA & 1 & 35 & 0 & & 0 & \\
\hline SENEGAL & 1 & 8 & 0 & & 0 & \\
\hline SINGAPORE & 1 & 12 & 0 & & 0 & \\
\hline SLOVAK REPUBLIC & 1 & 12 & 1 & 20 & 0 & \\
\hline SOUTH AFRICA & 1 & 25 & 1 & 25 & 1 & 25 \\
\hline SPAIN & 1 & 21,31 & 1 & 33 & 0 & \\
\hline SRI LANKA & 1 & 28 & 0 & & 0 & \\
\hline ST. VINCENT AND THE GRENADINES & 1 & 1,6 & 0 & & 0 & \\
\hline SWEDEN & 1 & 1 & 0 & & 0 & \\
\hline SWITZERLAND & 1 & 26 & 0 & & 0 & \\
\hline TAIWAN, CHINA & 1 & 15 & 0 & & 1 & 142 \\
\hline THAILAND & 1 & 48 & 1 & 49 & 1 & 49 \\
\hline TRINIDAD AND TOBAGO & 1 & 4 & 0 & & 0 & \\
\hline TURKEY & 1 & 21,35 & 1 & 35 & 1 & 166 \\
\hline UGANDA & 1 & 11 & 1 & 11 & 1 & 11 \\
\hline UKRAINE & 1 & 13 & 0 & & 0 & \\
\hline UNITED KINGDOM & & & & & & \\
\hline UNITED STATES & 1 & $5 \mathrm{am}$. & 0 & & 0 & \\
\hline URUGUAY & 1 & 7 & 1 & 32 & 0 & \\
\hline VENEZUELA* & 1 & 115 & 1 & 115 & 0 & \\
\hline ZAMBIA & 1 & 11 & 0 & & 0 & \\
\hline ZIMBABWE & 1 & 12,16 & 1 & 16 & 1 & $16 \mathrm{~A}$ \\
\hline Observations & 83 & & 83 & & 83 & \\
\hline
\end{tabular}

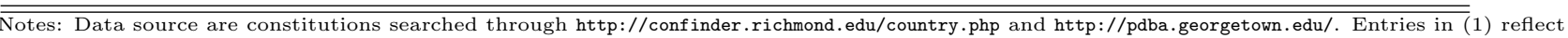
whether the constitution in the corresponding country contains an article referring to "property" that states the recognition and protection of private property. Entries in (2) are 0 if the respective articles mention that property rights are "inviolable", and 1 if they refer to a "social" purpose or function of private property. Constitutional articles allowing for the expropriation of private property in the context of national emergency or public need, mentioning the requirement of an appropriate compensation, are do not entail a coding of 1. Entries in (3) reflect whether the constitutional text contains the key words "land reform", "agrarian reform", "agrarian revolution". * Venezuela's constitution of 1999 eliminated the reference to land reform that was contained in article 115 of the 1961 constitution. Entries in columns (1) and (2) are unaffected, and refer to article 99 in the constitution of 1961 . The results are unaffected by which constitution is used. 